\title{
Impairment of CFTR activity in cultured epithelial cells upregulates the expression and activity of LDH resulting in lactic acid hypersecretion
}

\author{
Ángel G. Valdivieso ${ }^{1}$ - Mariángeles Clauzure ${ }^{1}$ - María M. Massip-Copiz ${ }^{1}$ Carla E. Cancio ${ }^{1}$ - Cristian J. A. Asensio ${ }^{1}$ \\ Consuelo Mori ${ }^{1}$ - Tomás A. Santa-Coloma ${ }^{1}$
}

Received: 3 October 2018 / Revised: 23 November 2018 / Accepted: 17 December 2018

(c) Springer Nature Switzerland AG 2019

\begin{abstract}
Mutations in the gene encoding the CFTR chloride channel produce cystic fibrosis (CF). CF patients are more susceptible to bacterial infections in lungs. The most accepted hypothesis sustains that a reduction in the airway surface liquid (ASL) volume favor infections. Alternatively, it was postulated that a reduced $\mathrm{HCO}_{3}{ }^{-}$transport through CFTR leads to a decreased ASL pH, favoring bacterial colonization. The issue is controversial, since recent data from cultured primary cells and CF children showed normal $\mathrm{pH}$ values in the ASL. We have reported previously a decreased mitochondrial Complex I (mCx-I) activity in cultured cells with impaired CFTR activity. Thus, we hypothesized that the reduced $\mathrm{mCx}-\mathrm{I}$ activity could lead to increased lactic acid production (Warburg-like effect) and reduced extracellular $\mathrm{pH}(\mathrm{pHe})$. In agreement with this idea, we report here that cells with impaired CFTR function (intestinal Caco-2/pRS26, transfected with an shRNA-CFTR, and lung IB3-1 CF cells) have a decreased pHe. These cells showed increased lactate dehydrogenase (LDH) activity, LDH-A expression, and lactate secretion. Similar effects were reproduced in control cells stimulated with recombinant IL-1 $\beta$. The c-Src and JNK inhibitors PP2 and SP600125 were able to increase the pHe, although the differences between control and CFTR-impaired cells were not fully compensated. Noteworthy, the LDH inhibitor oxamate completely restored the pHe of the intestinal Caco-2/pRS26 cells and have a significant effect in lung IB3-1 cells; therefore, an increased lactic acid secretion seems to be the key factor that determine a reduced pHe in these epithelial cells.
\end{abstract}

Keywords CFTR $\cdot$ Cystic fibrosis $\cdot$ Lactate $\cdot$ Oxamate $\cdot$ Extracellular pH $\cdot$ IL-1 $\beta \cdot$ Inflammation

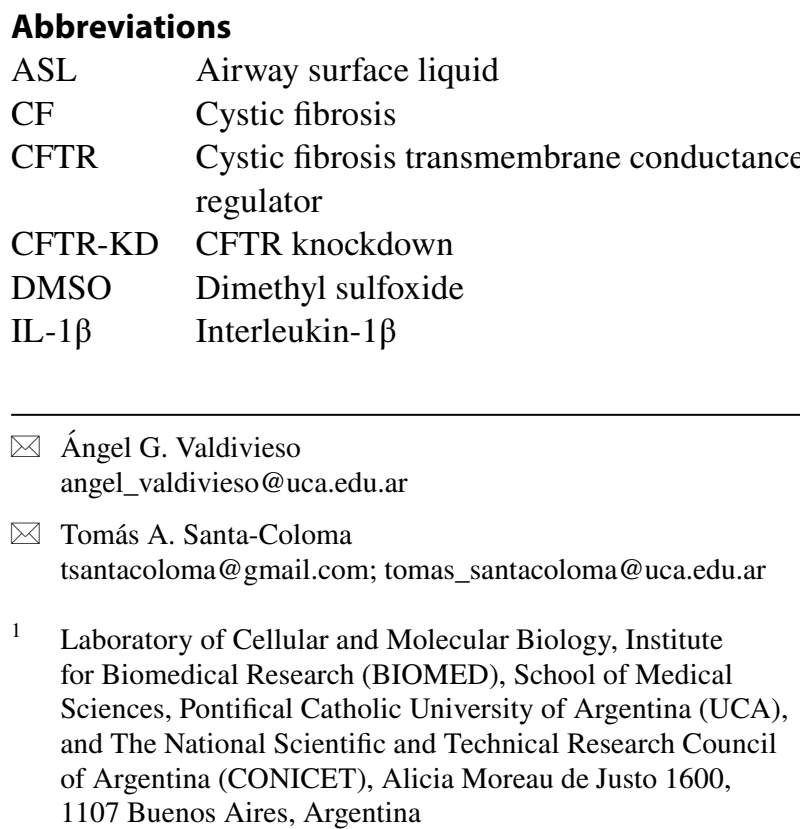

\section{Abbreviations}

$\mathrm{CF}$

$\begin{array}{ll}\text { JNK } & \text { JUN N-terminal kinase } \\ \text { LDH } & \text { Lactate dehydrogenase } \\ \text { mCx-I } & \text { Mitochondrial Complex I } \\ \text { pHe } & \text { Extracellular pH } \\ \text { shRNA } & \text { Short hairpin RNA }\end{array}$

Introduction

Cystic fibrosis (CF) is an autosomal recessive disease caused by mutations in the CFTR gene (cystic fibrosis transmembrane conductance regulator) [1]. The encoded protein, CFTR, is an integral membrane glycoprotein located in the apical region of epithelial cells [2] and functions as a cAMPactivated chloride channel [3]. For many years, the leading hypothesis for the development of airway lung disease in CF was that the CFTR impairment reduced the $\mathrm{Cl}^{-}$secretion, leading to a reduced interstitial $\mathrm{Na}^{+}$and $\mathrm{H}_{2} \mathrm{O}$ transport and increased sodium reabsorption through $\mathrm{ENaC}$ channel 
activation. The reduced $\mathrm{H}_{2} \mathrm{O}$ transport produced a decreased airway surface liquid (ASL) volume (dehydration), creating an environment favoring recurrent bacterial infections and chronic inflammation, which eventually lead to organ failure [4]. This hypothesis was later challenged, since the ASL was not found dehydrated/reduced in a pig model of CF, even though the animals develop spontaneous infections [5, 6]. To explain this observation, instead of an ASL dehydration, a reduced $\mathrm{HCO}_{3}{ }^{-}$transport concomitant with a reduced ASL $\mathrm{pH}$ has been then proposed, in agreement with the previous findings in $\mathrm{CF}$ cells [7]. The reduced extracellular $\mathrm{pH}$ $(\mathrm{pHe})$ in pigs was also linked to the increased susceptibility to spontaneous bacterial infections [5-7]. However, other authors do not agree, sustaining that the ASL pH in CF patients actually does not change $[8,9]$. Therefore, the issue is still controversial (reviewed in [10] and discussed recently here [11]).

More than 20 years ago, using differential display to study the differential expression of genes in CF cells, we found a series of CFTR-depending genes [12-14]; in other words, genes in which the CFTR $\mathrm{Cl}^{-}$transport activity modulates their expression. Other genes, such as RANTES, appear to be modulated by the presence of the CFTR at the cell membrane, independently of its $\mathrm{Cl}^{-}$transport activity, through its PDZ-interacting motif [15]. The first characterized was c-Src, which was found overexpressed in CF cells [14]. Its elevated activity resulted in the overexpression of the mucin MUC1; therefore, $\mathrm{c}-\mathrm{Src}$ appeared to constitute a bridge between the CFTR failure and the overexpression of mucins in CF [14]. Through differential display, we also selected two cDNA spots that, contrary to the increased expression of c-Src, showed a reduced expression in CF cells. Noteworthy, both spots corresponded to genes encoding mitochondrial proteins, MTND4 [16] and CISD1 [17], the last corresponding to a new human gene that we originally named ZCD1, which does not have a clear function yet [17]. Since MTND4 was essential for the assembly and activity of the mitochondrial Complex I ( $\mathrm{mCx}-\mathrm{I})$ [18], we then tested if the activity of this complex was affected in CF cells, as it was reported in the pioneer work of Shapiro et al. many years ago (reviewed in [19]), before the CFTR was cloned. As expected, we found a reduced $\mathrm{mCx}$-I activity in cultured $\mathrm{CF}$ cells or cells with impaired CFTR activity [19, 20]. Later, we found that this reduced $\mathrm{mCx}-\mathrm{I}$ activity was caused by an autocrine interleukin-1 $\beta$ (IL-1 $\beta$ ) loop [21]. Therefore, we hypothesized that a reduced $\mathrm{mCx}$-I activity could lead to an increased glycolysis, resulting in a high lactate production through a Warburg-like effect [22-25], contributing to an extracellular $\mathrm{pH}(\mathrm{pHe})$ reduction.

To test the above mentioned hypothesis (Warburg-like effect), here, we studied the $\mathrm{pHe}$ and lactic acid secretion in Caco-2/pRS26 shRNA-CFTR and IB3-1 CF epithelial cells, which have a reduced CFTR activity $[20,26,27]$. We observed a reduced $\mathrm{pHe}$ and increased lactate secretion in conditioned media from cultured cells with impaired CFTR activity. This rise in lactate and $\mathrm{H}^{+}$secretion (lactic acid) was accompanied by an increased lactate dehydrogenase (LDH) protein expression and activity. Interestingly, these changes were mimicked by IL- $1 \beta$ treatment, a cytokine that we found previously increased in CF cells and responsible for a decreased $\mathrm{mCx}-\mathrm{I}$ activity [21]. Noteworthy, the $\mathrm{pHe}$ was completely restored in Caco-2/pRS26 cells incubated in the presence of the LDH inhibitor oxamate, suggesting that the increased production of lactate was responsible for the decreased pHe observed in cells with impaired CFTR activity. Thus, Caco-2/pRS26 cells and IB3-1 cells, having an impaired CFTR activity, have increased LDH protein and activity, produce higher lactate and a reduced $\mathrm{pHe}$ in vitro. Thus, at least in vitro, these cells with impaired CFTR activity secrete more lactic acid, which is mostly responsible for the reduced $\mathrm{pHe}$.

\section{Materials and methods}

\section{Reagents}

Interleukin-1 beta (IL-1 $\beta$, I9401), L(+)-lactic acid free acid (Cat. \#L1750-10G) and DMSO culture grade were purchased from Sigma-Aldrich (St. Louis, MO). IKK-2 inhibitor (SC-514) and c-Src inhibitor (4-amino-5-(4chlorophenyl)-7-(t-butyl) pyrazolo [3,4-d] pyrimidine, $\mathrm{PP} 2$ ) were from Calbiochem (San Diego, CA). p38 MAP kinase inhibitor (SB203580), MAP kinase kinases MEK1/2 inhibitor (U0126), and Jun N-terminal kinase (JNK) inhibitor (SP600125) were from Alomone Labs (Jerusalem, Israel); the LDH inhibitors GNE-140 (racemate) and GSK2837808A were from MCE (MedChemExpress, Monmouth Junction, $\mathrm{NJ})$. All other reagents were analytical grade. The stock solutions of pathway inhibitors were prepared at $1000 \times$ in culture-grade DMSO. Antibodies: anti-rabbit antibody coupled to horseradish peroxidase (polyclonal, W401B) was from Promega (Madison, WI); rabbit polyclonal anti-actin antibody (A2066) and rabbit FITC-conjugated secondary antibody were from Sigma-Aldrich, and rabbit monoclonal antibody anti-LDH-A (C4B5, Rabbit mAb \#3582, Lot: 4) was from Cell-Signaling Technology (Danvers, MA).

\section{Cells}

IB3-1 (CRL-2777) and C38 (CRL-2779) cells were purchased from ATCC (now available at John Hopkins University). IB3-1 cells are bronchial epithelial cells derived from a $\mathrm{CF}$ patient that exhibited the most frequent mutation $\Delta$ F508 in one allele [28]. These cells also have the non-sense mutation $\mathrm{W} 1282 \mathrm{X}$ in the second allele, which 
also determines by itself a severe disease [29]. The IB3-1 cells have been immortalized using the hybrid adenovirus adeno-12-SV40 [27, 30]. C38 cells are IB3-1 cells transduced with an adeno-associated viral vector to stably express a functional CFTR, in a truncated version [31]. The relative activity of IB3-1 cells and C38 cells was measured previously by Flotte et al. [32]. It is higher in C38 than IB3-1 cells and contrary to IB3-1, the CFTR activity of $\mathrm{C} 38$ cells respond to PKA stimulation. Caco-2/ pRS26 cells, which are Caco-2 intestinal cells that stably express an shRNA plasmid directed against CFTR, and Caco-2/pRSctrl control cells, transfected with a noneffective shRNA plasmid against GFP as negative control, were cultured as previously described $[20,21]$. Caco-2/ pRS26 cells have a lower CFTR activity than Caco-2/pRS control cells $(\sim 25 \%)$ [26]. Puromycin treatment $(1 \mu \mathrm{g} /$ $\mathrm{ml}$ ) was discontinued before performing the experiments. All cell lines were cultured in DMEM/F12 with $15 \mathrm{mM}$ $\mathrm{HCO}_{3}{ }^{-}$and $15 \mathrm{mM}$ HEPES (Cat. No. 12500-096, Life Technologies, GIBCO BRL, Rockville, MD) supplemented with 10\% FBS (Internegocios S.A., Mercedes, Buenos Aires, Argentina), $100 \mathrm{U} / \mathrm{ml}$ penicillin, and $100 \mu \mathrm{g} / \mathrm{ml}$ streptomycin (Life Technologies, GIBCO BRL, Rockville, MD). Cultures were grown in a humidified atmosphere containing $5 \% \mathrm{CO}_{2}$ at $37^{\circ} \mathrm{C}$. Before treatments, cells were incubated $24 \mathrm{~h}$ in serum-free medium, to reach basal conditions, and then, the serum-free medium was renewed, and the cells were cultured for additional $48 \mathrm{~h}$ or $72 \mathrm{~h}$, depending on the cell line and the treatments. The cells were also treated with IL-1 $\beta(5 \mathrm{ng} / \mathrm{ml})$, and with the IL- $1 \beta$ pathway inhibitors of JNK (SP600125, $5 \mu \mathrm{M})$, c-Src (PP2, $10 \mu \mathrm{M})$, P38 MAPK (SB203580, $5 \mu \mathrm{M}$ ), MEK1/2 (U0126, $5 \mu \mathrm{M}$ ), and IKK (IKK-2 inhibitor, $5 \mu \mathrm{M}$ ). The concentrations used were as previously reported [21]. Cells were also treated with the LDH inhibitors GNE-140 [33] and GSK-2837808A [34], both at $1 \mu \mathrm{M}$ concentrations. In both cases, the pHe response reached a plateau at concentrations below $1 \mu \mathrm{M}$ (results not shown). The incubations with these inhibitors were performed in the second $48 \mathrm{~h}$ period, in serum-free media.

\section{Measurement of the extracellular pH (pHe)}

Cells were cultured in p60 culture dishes, plated at $5 \times 10^{4}$ cells $/ \mathrm{cm}^{2}\left(1 \times 10^{6}\right.$ cells $/$ dish $)$ in $3 \mathrm{ml}$ of culture medium. After incubation in serum-free medium at the time indicated for each experiment, the $\mathrm{pHe}$ was measured in the conditioned media using a pH meter (UltraBasic UB-10, Denver Instrument, Bohemia, NY). To avoid pHe changes in the culture medium due to atmospheric equilibration, each plate was maintained in the incubator containing $5 \% \mathrm{CO}_{2}$ until it was rapidly measured using the $\mathrm{pH}$ meter.

\section{Extracellular lactate measurement}

Cells were seeded in 12 wells culture plates at a density of $4 \times 10^{4}$ cells $/ \mathrm{cm}^{2}\left(1 \times 10^{5}\right.$ cells/well $)$ in $0.8 \mathrm{ml}$ of culture medium containing 5\% FBS. Before treatments, cells were incubated $24 \mathrm{~h}$ in $0.8 \mathrm{ml}$ of serum-free medium to reach basal conditions, and then, the serum-free medium was replaced by new serum-free medium with or without treatments. After the second incubation in serum-free medium, a sample $(15 \mu \mathrm{l})$ of medium was collected at 5,24 , and $48 \mathrm{~h}$ to measure lactate secretion. The samples were centrifuged at $600 \times \mathrm{g}$ for $10 \mathrm{~min}$ at $4{ }^{\circ} \mathrm{C}$ and the lactate concentration was measured in the supernatants using the Lactate kit from Roche (Cat. \#11822837 190, Roche Diagnostics GmbH, Mannheim, Germany), with some modifications to adapt the measurements to 96 wells plates, which were measured in a Multiskan Spectrum spectrophotometer (Thermo Fisher Scientific, Vantaa, Finland). Briefly, the lactate calibration curve $(5,10,20,30,40,50$, and $100 \mu \mathrm{M})$ was made using a $150 \mathrm{mM}$ lactate stock solution prepared from $\mathrm{L}(+)$-lactic acid free acid dissolved in serum-free DMEM/F12 medium containing $15 \mathrm{mM}$ HEPES and neutralized to $\mathrm{pH} 7.4 \mathrm{using}$ a $1 \mathrm{M} \mathrm{KOH}$ solution. The samples (conditioned media) were diluted 1:100 and $150 \mu \mathrm{l} /$ well were loaded in 96 wells plates. The lactate kit reagents were mixed, $12.5 \mu \mathrm{l}$ of R1 (this solution is the hydrogen donor, ascorbate $\geq 30 \mathrm{U} / \mathrm{ml}$, buffer) and $2.5 \mu \mathrm{l}$ of R2 (4.9 mM 4-aminoantipyrine, lactate oxidase (LOD, microorganisms) $\geq 15 \mathrm{U} / \mathrm{ml}$, horseradish peroxidase $\geq 24 \mathrm{U} / \mathrm{ml}$, buffer) per well, and $15 \mu \mathrm{l} /$ well were added to the samples and the calibration curve. The spectrophotometric measurement was performed at $660 \mathrm{~nm}$ after 5 min of incubation at RT.

\section{Lactate dehydrogenase activity (LDH)}

Lactate dehydrogenase activity was determined spectrophotometrically by measuring the oxidation of NADH during the reduction of pyruvate to lactate (absorbance/min at $340 \mathrm{~nm}$ ) as previously reported [35].

\section{Confocal immunofluorescence and image analysis}

Caco-2/pRSctrl and Caco-2/pRS26 cells plated on coverslips in 24-well plates $\left(4 \times 10^{4}\right.$ cells $/$ well; $2 \times 10^{4}$ cells $\left./ \mathrm{cm}^{2}\right)$ were cultured for $48 \mathrm{~h}$ in $2 \mathrm{ml}$ of DMEM-F12 with or without serum 5\%. Immunocytochemistry was performed as previously described [14] with some modifications. Briefly, cells were rinsed twice in ice-cold PBS and fixed with a freshly prepared solution of $4 \%$ paraformaldehyde- $4 \%$ sucrose in PBS for 20 min at RT. Then, cells were rinsed 3 times in Tris-Buffered Saline $1 \times(\mathrm{TBS})$ and permeabilized with $0.1 \%$ Triton X-100 in TBS for 15 min at RT. After three washes in ice-cold TBS, cells were blocked with 5\% BSA-TBS for $1 \mathrm{~h}$ 
at room temperature. Then, cells were incubated with a primary anti-LDH-A antibody, dilution 1:200 in 5\% BSA-TBS plus Tween-20 $(0.05 \% \mathrm{v} / \mathrm{v})$ and incubated overnight at $4{ }^{\circ} \mathrm{C}$. After primary antibody incubation cells were washed three times with TBS plus Tween-20 $(0.05 \% \mathrm{v} / \mathrm{v})$ and incubated with FITC-conjugated secondary antibody, dilution 1:400 in the same buffer for $2 \mathrm{~h}$, at RT. Immunofluorescence images were captured with a Zeiss LSM 510 confocal microscope (Carl Zeiss, Jena, Germany) using a 63X/1.2 NA (numerical aperture) water-immersion objective. For FITC (Ex/Em: 490/525), a 488-laser line was used for excitation and an LP $505 \mathrm{~nm}$ filter for emission (green). LDH-A images from ten microscope fields for each condition of three independent experiments were registered.

\section{LDH-A quantification}

LDH-A was quantified by flow cytometry [36]. Briefly, Caco-2/pRSctrl and Caco-2/pRS26 cells were cultured in p60 plates $\left(4 \times 10^{5}\right.$ cells $/$ dish, density $2 \times 10^{4}$ cells $\left./ \mathrm{cm}^{2}\right)$ for $48 \mathrm{~h}$ in DMEM-F12 with or without $5 \%$ FBS. Cells were harvested by trypsin treatment and washed twice with PBS. Ice-cold samples containing $1 \times 10^{6}$ cells per $150 \mu$ of PBS were fixed by adding $50 \mu \mathrm{l}$ of paraformaldehyde-sucrose 4X (paraformaldehyde 4\%-sucrose 4\% final concentration) to each tube and incubated for $15 \mathrm{~min}$ at $4{ }^{\circ} \mathrm{C}$. Cells were washed three times with PBS plus $0.2 \%$ Tween 20 (PBST) and centrifuged at $400 \times g$ for $5 \mathrm{~min}$. Unspecific binding sites were blocked with 5\% BSA in PBS for $30 \mathrm{~min}$ and washed two times with PBS-T and centrifuged at $400 \times g$ for $5 \mathrm{~min}$. Cells were incubated with $50 \mu \mathrm{l}$ of the anti-LDHA rabbit antibody diluted 1:200 and incubated over night at $4{ }^{\circ} \mathrm{C}$. Then, cells were washed four times with PBS-T and centrifuged at $400 \times g$ for $5 \mathrm{~min}$. Cells were incubated with $50 \mu \mathrm{l}$ of the anti-rabbit-FITC antibody diluted 1:400, incubated $1 \mathrm{~h}$ at RT, and washed three times with PBS-T. Finally, cells were pelleted by centrifugation at $400 \times g$ for $5 \mathrm{~min}$, resuspended in $300 \mu \mathrm{l}$ of ice-cold PBS, and ran on the flow cytometer (Accuri, BD Biosciences, San José, CA). To quantify the LDH-A content, the mean of fluorescence intensity (MFI) was measured and the results were expressed as mean $\pm \mathrm{SE}$ of three independent experiments, each performed by triplicates.

\section{Statistics}

Unless otherwise indicated, the results corresponded to the average of three independent experiments (mean \pm SEM, $n=3$ ). The different curves and regressions were fitted on the mean at each concentration point and SE weighted using the software Origin (OriginLab Co.); the $R^{2}$ values were used to obtain the corresponding $t$ values: $t=\sqrt{R^{2}(n-2) /\left(1-R^{2}\right)}$ [37] and the corresponding $p$ values. One-way ANOVA and the Tukey's test were applied to determine significant differences among samples $(p<0.05)$. The values passed the Levene's test for homoscedasticity [38] and the Shapiro-Wilk's normal distribution test [39]. However, since the number of means was small (in most cases $n=3$ ), the differences in the graphs with bars were also analyzed using the Kruskal-Wallis non-parametric test [40] and the Mann-Whitney test [41]. If a difference occurred between the significance of the parametric vs the non-parametric test, this was indicated in the legend of the figure. Some differences were compared using the Student's (W.S. Gosset) test [42]. In all figures, $* p<0.05, * * p<0.01$, and ${ }^{* * *} p<0.001$.

\section{Results}

\section{Cells with impaired CFTR activity produce hyperacidity in the extracellular medium}

To study the possible influence of the CFTR activity on $\mathrm{pHe}$, we used two epithelial cell lines of different origins (intestine and lung), which have an affected CFTR activity through different ways. We first used Caco-2 colon carcinoma cells (normal CFTR activity), transfected with an shRNA against CFTR (Caco-2/pRS26 cells), and their control expressing an shRNA against GFP (a protein not present in these Caco-2/pRSctrl cells) [20, 26]. As shown in Fig. 1a, after incubation for $72 \mathrm{~h}$ in serum-free medium, the pHe was significantly $(p<0.001)$ decreased in the CFTR knockdown (CFTR-KD) Caco-2/pRS26 cells $(7.23 \pm 0.02$, $n=7)$ compared to Caco-2/pRSctrl cells $(7.42 \pm 0.03, n=7)$, with a $\Delta \mathrm{pHe}=0.19 \pm 0.04$. To confirm that a CFTR failure induces a decreased $\mathrm{pHe}$, we then used IB3-1 airway CF cells, which instead of a CFTR-KD have a mutated CFTR ( $\Delta$ F508/W1282X genotype) [27, 30]. As control, we used C38 cells, which are IB3-1 "corrected cells" transduced with a viral vector expressing a truncated wt-CFTR [28]. As shown in Fig. 1b, the pHe was significantly $(p<0.01)$ decreased in IB3-1 cells $(7.02 \pm 0.04, n=3)$ compared with C38 cells $(7.32 \pm 0.08, n=3)$, reinforcing the idea that a CFTR failure promotes a reduction in the $\mathrm{pHe}$.

\section{The impairment of the CFTR activity increases lactate secretion and LDH-A expression}

To study the possible mechanisms that might lead to a reduced $\mathrm{pHe}$, we first measured the lactate secretion in Caco-2/pRS26 and Caco-2/pRSctrl cells, incubated in serum-free media for $24 \mathrm{~h}$ before measurements (time 0 ). As shown in Fig. 2a, the lactate secretion increased linearly with time in both cell lines. The total lactate secretion was significantly $(p<0.001)$ increased in Caco- $2 /$ pRS26 cells compared to Caco-2/pRSctrl at $24 \mathrm{~h}(7.47 \pm 0.2$ 

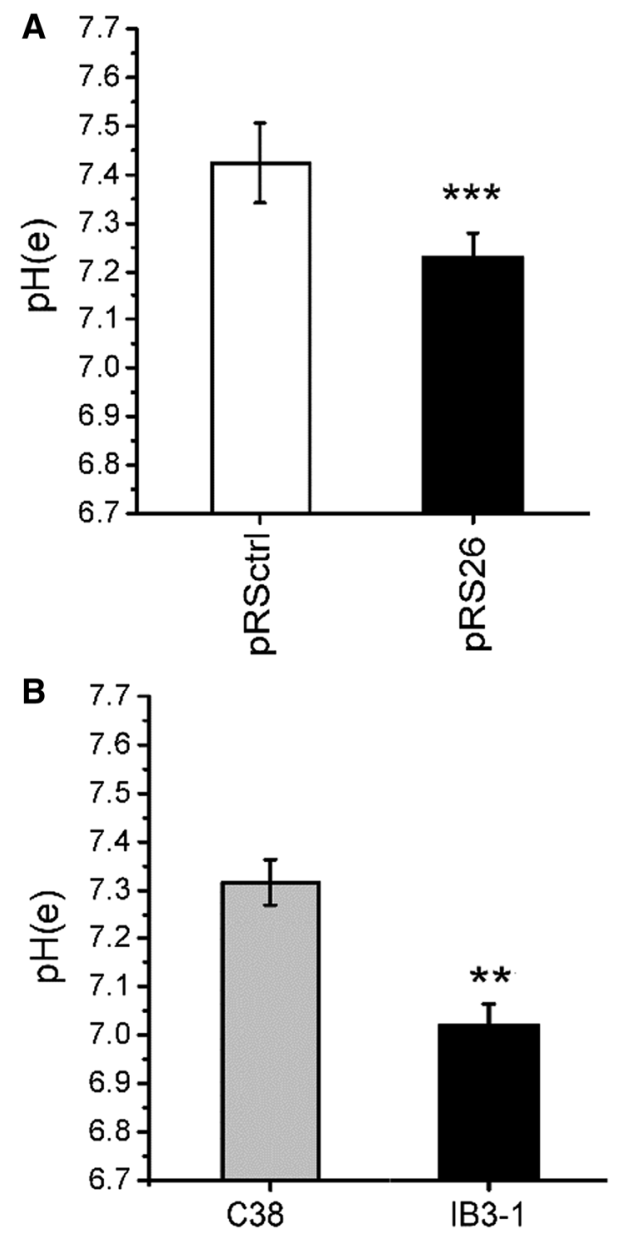

Fig. 1 Impairment of the CFTR activity decreased the extracellular $\mathrm{pH}(\mathrm{pHe})$. a $\mathrm{pH}$ of conditioned media from Caco-2/pRSctrl (Caco-2 cells with wt-CFTR transfected with a control shRNA plasmid) (open bar) and Caco-2/pRS26 cells (Caco-2 cells stably expressing shRNACFTR) (closed bar) after $72 \mathrm{~h}$ incubation in serum-free medium. Results were expressed as mean $\pm \mathrm{SE}, n=7$ independent experiments. $* * * p<0.001 \mathbf{b} \mathrm{pHe}$ of conditioned media from C38 cells (IB3-1 cells "corrected" with wt-CFTR, grey bar) and IB3-1 cells (CF cells, closed bar) after $72 \mathrm{~h}$ incubation in serum-free medium. The results were expressed as mean $\pm \mathrm{SE}, n=3$ independent experiments. $* * p<0.01$. One-way ANOVA tests were performed. In addition, the Mann-Whitney non-parametric median analysis showed $p<0.01$ for panel A and $p<0.05$ for $\mathbf{b}$

vs $4.91 \pm 0.35 \mathrm{mM}, n=4)$ and $48 \mathrm{~h}(12.36 \pm 0.31$ vs $8.55 \pm 0.29, n=4)$ of incubation. The rate for lactate production was significantly $(p<0.05)$ higher in Caco-2/pRS26 cells (slope $=0.23 \pm 0.06, n=4$ ) than in Caco- $2 / p R S c t r l$ (slope $=0.16 \pm 0.06, n=4$ ). In agreement with these results, the intracellular LDH activity showed a significant rise $(p<0.001)$ in Caco-2/pRS26 $(166.4 \% \pm 8.2, n=5)$ compared to Caco-2/pRSctrl $(100 \% \pm 5.8, n=5)$ after $48 \mathrm{~h}$ of incubation in serum-free medium (Fig. 2b). We then studied if the increased LDH activity correlated with LDH-A expression. First, using confocal microscopy, the LDH-A location in
Caco-2/pRSctrl and Caco-2/pRS26 cells was observed by immunofluorescence, and the influence of the serum presence in the incubation medium was analyzed (Fig. 2c). LDH-A was mainly located in the cytoplasm in both cell lines, either incubated in serum-free media or in the presence of FBS, for $48 \mathrm{~h}$. On the other hand, LDH-A protein expression was measured by cytometric quantification of Caco-2/pRSctrl and Caco-2/pRS26 cells incubated in serumfree medium (Fig. 2Da and b) or in the presence of 5\% FBS (c and d) for $48 \mathrm{~h}$. Results were plotted as FL1-A (Fluorescence intensity) vs FSC-A (forward scattering). LDH-A expression levels were also expressed as Media Fluorescence Intensity (MFI) (Fig. 2De). LDH-A expression was significantly higher $(p<0.05, n=3)$ in Caco-2/pRS26 cells than in Caco-2/pRSctrl cells (Fig. 2De). These results suggest that LDH-A expression is up-regulated in cells with impaired CFTR activity (Caco-2/pRS26 cells), in agreement with the observed increase in LDH activity and lactate secretion.

To confirm these results, the lactate secretion and LDH activity were also measured in IB3-1 cells (CFTR-mutated, CF cells) and C38 cells (IB3-1 "corrected" cells). As shown in Fig. 2e, the lactate secretion in IB3-1 cells was significantly $(p<0.05)$ increased compared to C 38 cells, after $72 \mathrm{~h}$ of incubation in serum-free medium. On the other hand, IB3-1 cells showed a significantly $(p<0.01)$ increased LDH activity $(201.4 \% \pm 21.4, n=3)$ compared to C38 cells $(100 \% \pm 12.2, n=3)$, in agreement with the observed increased lactate secretion and a reduced pHe of IB3-1 cells. Altogether, these results suggest that the impaired CFTR activity (CFTR-KD or CFTR-mutated) induces an increased activity of $\mathrm{LDH}$, which resulted in an increased lactate secretion and a reduced $\mathrm{pHe}$. The $\mathrm{pHe}$ is reduced, since lactate is transported together with $\mathrm{H}^{+}$through MCTs symporters [43-45].

\section{IL-1 $\beta$ treatment reduces the extracellular $\mathrm{pH}$ increasing lactate production}

We have reported that the impairment of the CFTR activity results in $\mathrm{Cl}^{-}$accumulation and IL- $1 \beta$ overexpression and secretion; in turn, the secreted IL- $1 \beta$ creates an autocrine positive feed-back loop that enhances its own signal, increases the oxidative stress, and reduces the $\mathrm{mCx}-\mathrm{I}$ activity [21, 26, 46-49]. Therefore, here, we study possible effects of recombinant IL-1 $\beta$ on pHe. Caco-2/pRSctrl cells were incubated with different IL- $1 \beta$ concentrations $(0.25$, $0.5,0.75,1.0,2.5$, and $5 \mathrm{ng} / \mathrm{ml}$ ) for $48 \mathrm{~h}$, in serum-free medium, and the pHe was measured. As shown in Fig. 3a, IL-1 $\beta$ reduced the $\mathrm{pHe}$ in a dose-dependent manner, with an $\mathrm{EC}_{50}=0.21 \pm 0.02 \mathrm{ng} / \mathrm{ml}$ (exponential decay curve, $p<0.01$, $n=7, R^{2}=0.95$ ). In addition, Caco- $2 / \mathrm{pRS}$ ctrl cells treated with $5 \mathrm{ng} / \mathrm{ml}$ of IL-1 $\beta$ for $48 \mathrm{~h}$ showed a reduction in the $\mathrm{pHe}(6.88 \pm 0.03, n=3)$ that reached almost the same value 

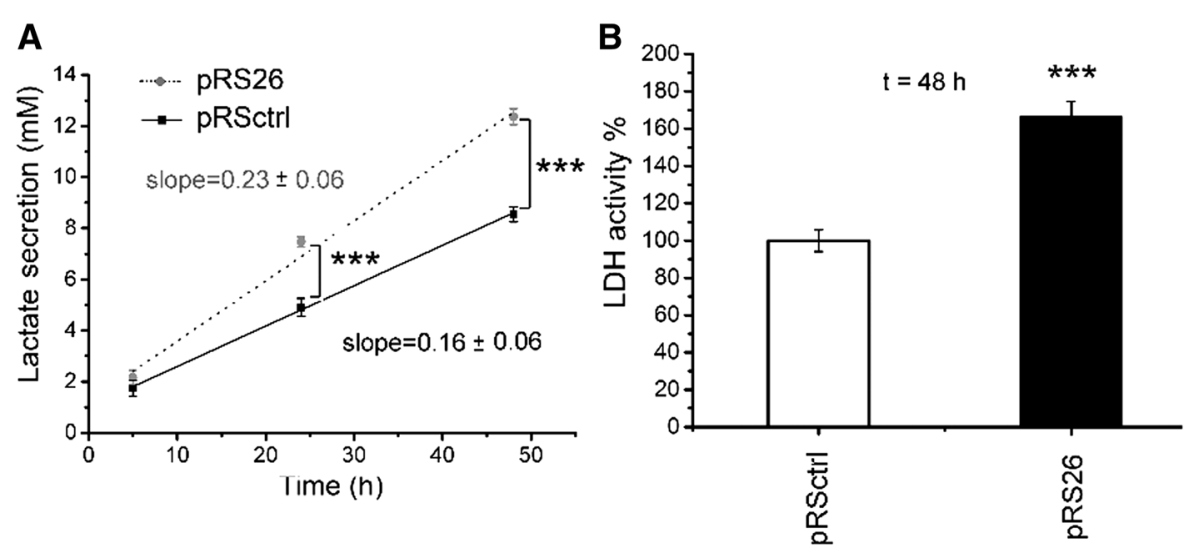

C

CONFOCAL

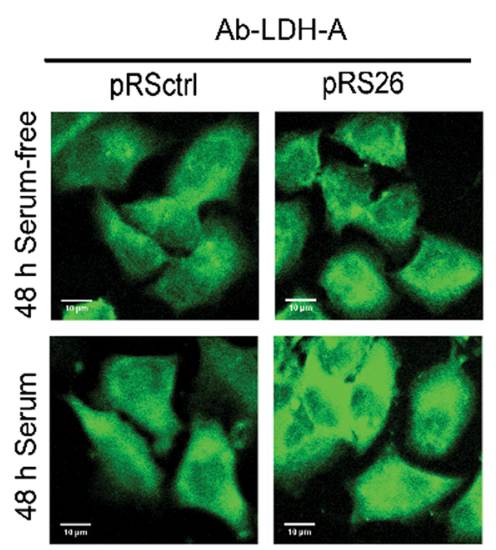

D

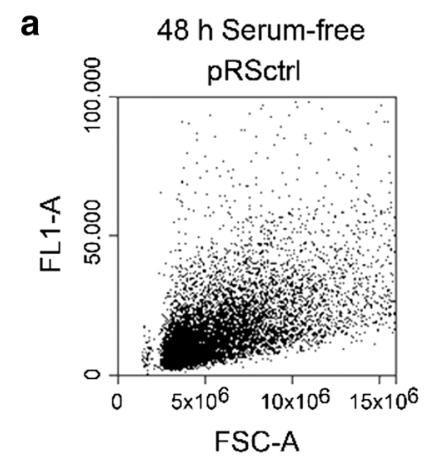

c

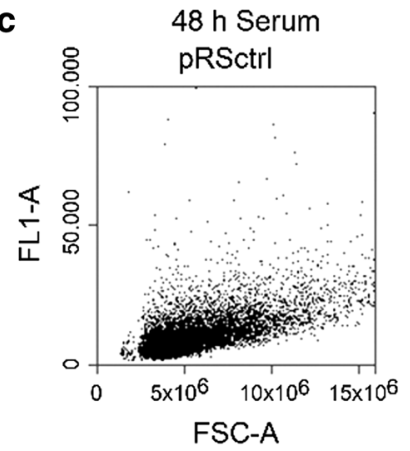

E

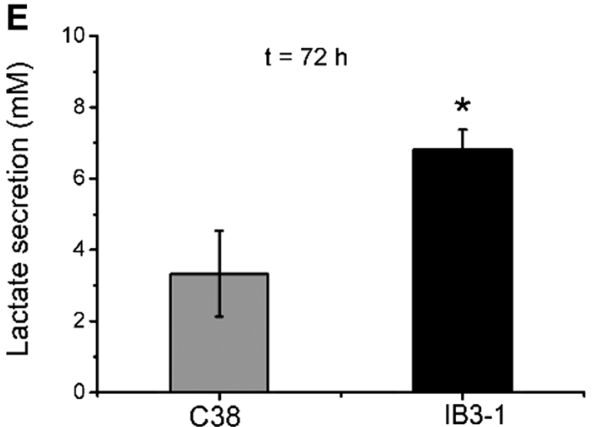

\section{b $\quad 48 \mathrm{~h}$ Serum-free}

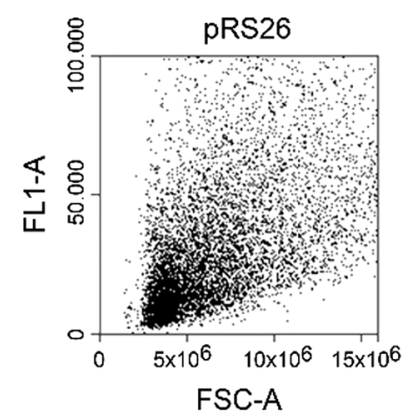

d

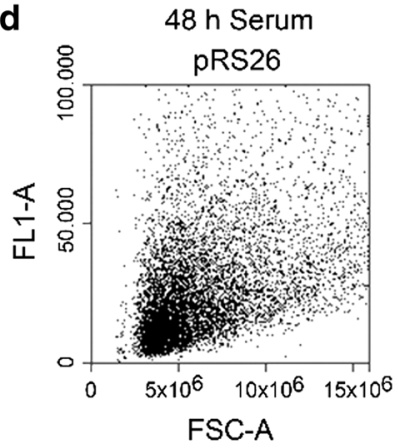

e

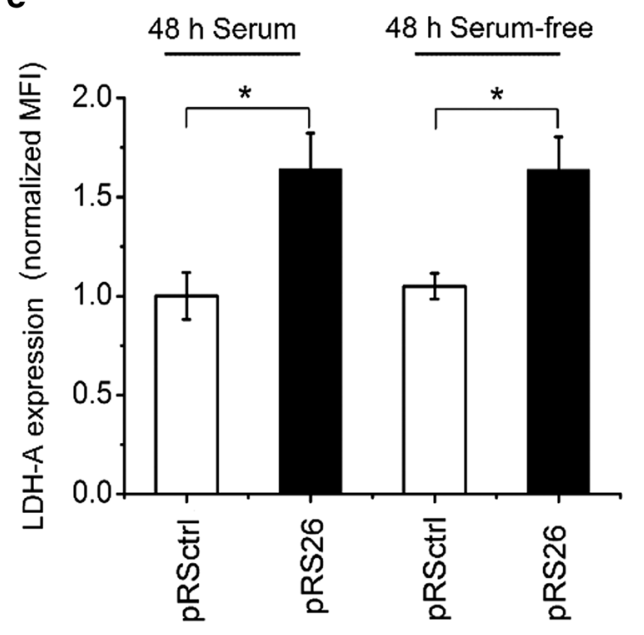

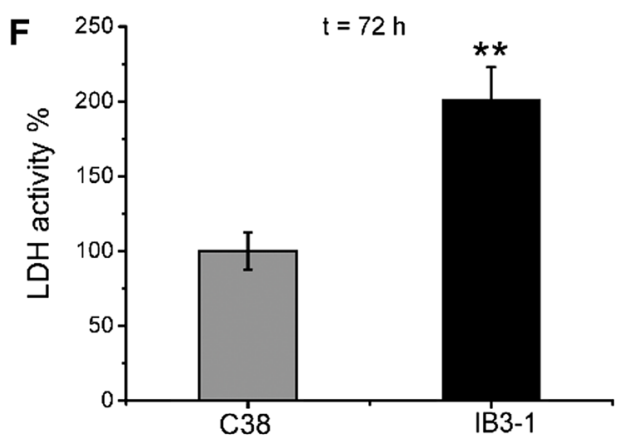

of Caco-2/pRS26 cells $(6.87 \pm 0.04, n=3)$ (Fig. 3b). On the other hand, IL-1 $\beta(5 \mathrm{ng} / \mathrm{ml})$ induced a time-dependent linear increase in the lactate secretion in Caco-2/pRSc$\operatorname{trl}(12.5 \pm 1.4 \mathrm{mM}, n=3,48 \mathrm{~h})$, showing similar lactate secretion than Caco-2/pRS26 cells without externally added IL-1 $\beta(12.4 \pm 0.6 \mathrm{mM}, n=3,48 \mathrm{~h})$ (Fig. 3c). In addition, in agreement with the increased lactate secretion, the LDH activity increased in Caco-2/pRSctrl cells $(154.5 \pm 24.5 \%$, 
४Fig. 2 Lactate secretion, LDH activity and LDH expression of cells with impaired CFTR activity. a Lactate concentration in conditioned media from Caco-2/pRSctrl cells (solid line) and Caco-2/pRS26 cells (dotted line) at 5, 24 and $48 \mathrm{~h}$. The results were fitted using a linear regression. The slopes are indicated and had a significant difference $(p<0.05)$. ***Highly significant differences $(p<0.001)$ compared to Caco-2/pRSctrl at each time point (ANOVA one-wayTukey's test, $n=4$ independent experiments). b Intracellular LDH activity measured in Caco-2/pRSctrl and Caco-2/pRS26 cells incubated $48 \mathrm{~h}$ in serum-free medium; the activity values were normalized taken Caco-2/pRSctrl as $100 \%$. ***Highly significant differences $(p<0.001, n=5$, one-way ANOVA). c Caco-2/pRSctrl and Caco-2/pRS26 cells were incubated with $5 \%$ FBS or in serum-free medium for $48 \mathrm{~h}$. Confocal immunofluorescence was performed to detect LDH-A (representative micrographs of 3 independent experiments). d Cytometry was performed to quantify LDH-A expression. FL1-A (fluorescence intensity) vs FSC-A (forward scattering) plots are shown for Caco-2/pRSctrl and Caco-2/pRS26 cells incubated in serum-free medium $(\mathbf{a}, \mathbf{b})$ or in the presence of $5 \%$ FBS (c and d) for $48 \mathrm{~h}$. LDH-A expression was indicated as mean fluorescence intensity (MFI) and normalized to control values (e). ${ }^{*} p<0.05$ (one-way ANOVA-Tukey's test). e Lactate secretion of C38 cells (grey bar) and IB3-1 (CF cells, black bar), preincubated $24 \mathrm{~h}$ in serum-free medium and then measured at $72 \mathrm{~h}$ of incubation in serum-free medium. ${ }^{*} p<0.05, n=3$ (one-way ANOVA). f Intracellular LDH activity in IB3-1 (CF cells, black bar) and C38 cells (grey bar), measured before $72 \mathrm{~h}$ of incubation in serum-free medium, referred at C38 as $100 \%$ of activity, $n=3$. ${ }^{*} p<0.01$ (one-way ANOVA). In addition, the MannWhitney non-parametric median analysis showed $p<0.05$ for $\mathbf{b}$

$n=4,48 \mathrm{~h}$ ) by IL- $1 \beta$ treatment compared to untreated cells, almost reaching the LDH activity in Caco-2/pRS26 cells $(165.7 \pm 6.7 \%, n=4,48$ h) (Fig. 3d). Overall, these results show that IL- $1 \beta$ increase the LDH activity and lactate secretion, resulting in a reduced $\mathrm{pHe}$.

\section{IL-1 $\beta$ decreases the extracellular $\mathrm{pH}$ through JNK and c-Src signaling}

To study the possible mechanism by which $\mathrm{IL}-1 \beta$ regulates the $\mathrm{pHe}, \mathrm{Caco}-2 / \mathrm{pRSctrl}$ and Caco-2/pRS26 cells were treated with inhibitors of different kinases involved in the IL-1 $\beta$ signaling (P38, JNK, MEK 1/2, and c-Src), as previously described [21]. The P38 MAPK inhibitor (SB203580) and the MEK1/2 inhibitor (U0126) did not produce a significant effect on the pHe (Fig. 4a). Conversely, JNK (SP600125) and c-Src (PP2) inhibitors increased significantly $(p<0.05)$ the $\mathrm{pHe}$ in Caco-2/pRSctrl and Caco-2/pRS26 cells (Fig. 4b, c), suggesting a role of these kinases in the pHe reduction. A dose-response $\mathrm{pHe}$ increase was observed when cells were treated with increased concentrations of the JNK inhibitor SP600125 $\left(\mathrm{EC}_{50}=2.3 \pm 0.6 \mu \mathrm{M}, n=4\right.$ for Caco-2/pRSctrl and $\mathrm{EC}_{50}=2.9 \pm 1.8 \mu \mathrm{M}, n=4$, for Caco-2/pRS26) or the c-Src inhibitor PP2 $\left(\mathrm{EC}_{50}=0.5 \pm 0.1 \mu \mathrm{M}, n=4\right.$, for Caco-2/ pRSctrl and $\mathrm{EC}_{50}=0.4 \pm 0.1 \mu \mathrm{M}, n=4$, for Caco-2/pRS26). However, a $\Delta \mathrm{pHe}$ remains between Caco-2/pRSctrl and Caco-2/pRS26 cells, even in the presence of saturating concentrations of SP600125 or PP2 (Fig. 4b, c), or adding both together (results not shown), suggesting that additional signaling should be involved in the pHe regulation, accounting for the remaining $\Delta \mathrm{pH}$.

\section{JNK and c-Src modulates lactate production and LDH activity}

As shown in Fig. 5a, after 48 h, inhibition of JNK kinase with $10 \mu \mathrm{M}$ SP60125 significantly $(p<0.05)$ decreased the lactate secretion in both Caco-2/pRS26 cells (untreated cells $12.4 \pm 0.6 \mathrm{mM}$ vs treated cells $9.4 \pm 1.3 \mathrm{mM}, n=3$ ) and in Caco-2/pRSctrl cells (untreated cells $8.5 \pm 0.6 \mathrm{mM}$ vs treated cells $6.3 \pm 1.7 \mathrm{mM}, n=3$ ). JNK inhibition with $10 \mu \mathrm{M}$ SP60125 also induced a significant $(p<0.05)$ decrease in the LDH activity in Caco-2/pRS26 cells $(53.3 \% \pm 12.8, n=3)$ compared with untreated Caco-2/pRS26 cells $(166.4 \% \pm 8.2$, $n=3$ ) (Fig. 5b). c-Src inhibition using $5 \mu \mathrm{M}$ PP2 for $48 \mathrm{~h}$ produced similar results. There was a significant $(p<0.001)$ reduction in the secreted lactate in Caco-2/pRS26 cells (untreated cells $12.4 \pm 0.6$ vs treated cells $7.7 \pm 0.9 \mathrm{mM}$, $n=3$ ) and Caco-2/pRSctrl cells (untreated cells $8.5 \pm 0.6$ vs treated cells $5.1 \pm 0.9 \mathrm{mM}, n=3$ ) (Fig. $5 \mathrm{c}$ ). In addition, the LDH activity in cells treated with PP2 was significantly $(p<0.05)$ decreased in Caco-2/pRS26 cells $(51.8 \% \pm 15.6$, $n=3)$ compared with their respective untreated Caco- $2 /$ pRS26 cells ( $166.4 \% \pm 8.2, n=3$ ) (Fig. 5d). Altogether, these data suggest that JNK and c-Src activities are involved on the pHe reduction of CFTR downregulated cells, somehow increasing the LDH activity and consequently the extracellular lactate.

\section{LDH inhibition restores the pHe in cells with impaired CFTR}

Caco-2/pRSctrl cells and Caco-2/pRS26 cells were incubated with increased concentration of the LDH inhibitor oxamate (0-60 mM [34]) for $48 \mathrm{~h}$. As shown in Fig. 6a, oxamate increased the pHe of Caco-2/pRS26 and Caco-2/ pRSctrl cells in a dose-response manner (fitted with a sigmoidal function). Contrary to the results obtained with PP2 and SP600125 that only partially restored the pHe, oxamate was able to fully restore the $\mathrm{pHe}$, reaching almost the same value in oxamate treated Caco-2/pRS26 $(7.42 \pm 0.02$, $n=3)$ or in Caco-2/pRSctrl cells $(7.46 \pm 0.02, n=3)$, cultured for $48 \mathrm{~h}$. In addition, $60 \mathrm{mM}$ oxamate induced a significant $(p<0.001)$ decrease of the lactate secretion in both cell lines, Caco-2/pRS26 $(4.95 \pm 0.42 \mathrm{mM}, n=3)$ or Caco-2/pRSctrl cells $(3.08 \pm 0.09 \mathrm{mM}, n=3)$ compared with untreated Caco-2/pRS26 cells $(12.36 \pm 0.31 \mathrm{mM}$, $n=3$ ), after $48 \mathrm{~h}$ of treatment (Fig. $6 \mathrm{~b}$ ). The LDH activity was also significantly $(p<0.05)$ decreased in Caco-2/ pRS26 $(65.9 \% \pm 9.5, n=3)$ treated with oxamate $(60 \mathrm{mM})$ compared with non-treated Caco-2/pRS26 $(166.4 \% \pm 8.2$, 

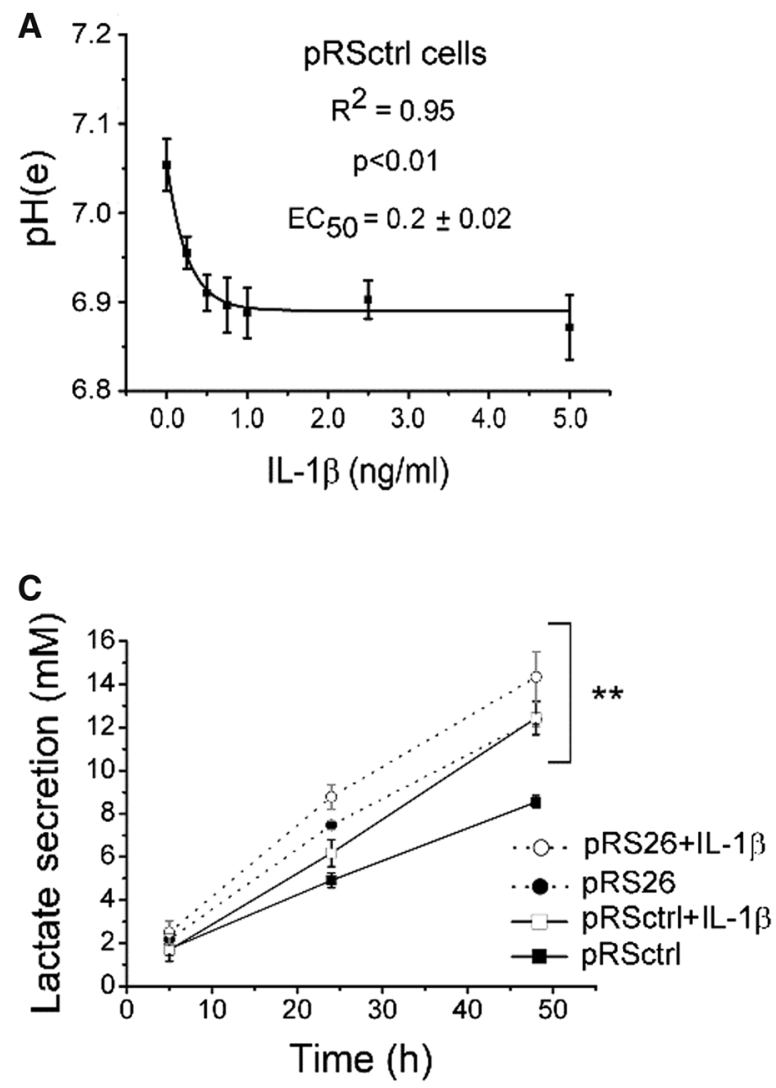
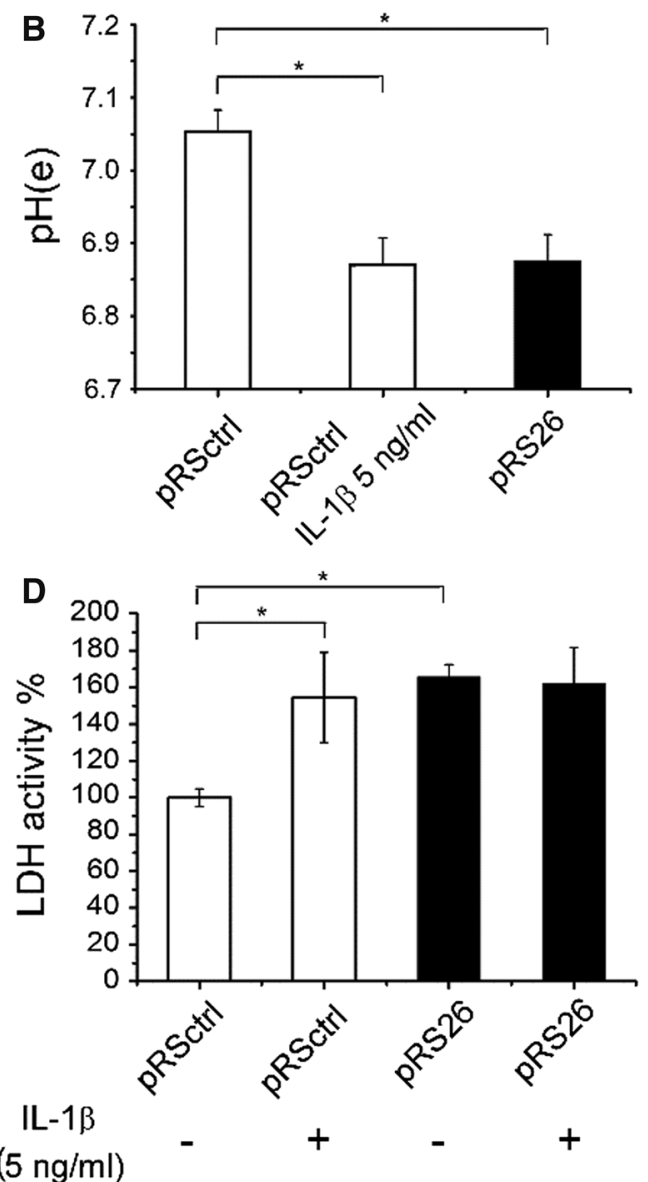

$(5 \mathrm{ng} / \mathrm{ml})$
Fig. 3 Interleukin-1 $\beta$ decreases $\mathrm{pHe}$ increasing lactate secretion and LDH activity. a pHe was measured in conditioned media from Caco-2/pRSctrl cells, previously incubated in serum-free medium for $24 \mathrm{~h}$, and then treated with different concentrations of recombinant $\mathrm{IL}-1 \beta(0.25,0.5,0.75,1.0,2.5$ and $5 \mathrm{ng} / \mathrm{ml})$, for $48 \mathrm{~h}$ in serum-free medium. The pHe decreased over time with an $\mathrm{EC}_{50}=0.21 \pm 0.02 \mathrm{ng} /$ $\mathrm{ml}(n=7)$ (exponential decay curve, $\left.p<0.01, R^{2}=0.95\right)$. b pHe of Caco-2/pRSctrl, Caco-2/pRSctrl treated with $5 \mathrm{ng} / \mathrm{ml}$ of IL- $1 \beta$ cells and Caco-2/pRS26 cells. * indicates $p<0.05, n=7$. c Lactate secreted into the culture media of non-treated (filled square-Caco- $2 / \mathrm{pRSc}$ trl and filled circle-Caco- $2 / \mathrm{pRS} 26)$ and IL-1 $\beta(5 \mathrm{ng} / \mathrm{ml})$ treated

$n=3)$, approaching the activity observed in treated Caco-2/ pRSctrl cells $(84.03 \% \pm 7.44, n=3)$ (Fig. 6c).

To test if $\mathrm{LDH}$ inhibition could also restore the increased pHe in CF cells, IB3-1 CF cells and C38 cells (expressing a functional CFTR) were incubated with increased concentration of oxamate $(0-60 \mathrm{mM})$ for $72 \mathrm{~h}$ in serum-free medium (Fig. 7a). In close similarity to the results observed with Caco-2 cells, oxamate increased the pHe of IB3-1 and C38 cells in a dose-response manner. Although the $\mathrm{pHe}$ increases were most pronounced in IB $3-1$ cells than in C38 cells, they were not enough to reach an even pHe value as observed in Caco- 2 cells at oxamate $60 \mathrm{mM}$, and a $\Delta$ pHe remains. We also tested two additional inhibitors of LDH-A, GNE-140 $(1 \mu \mathrm{M})$, and GSK2837808A $(1 \mu \mathrm{M})$, that are much potent (unfilled square-Caco-2/pRSctrl and unfilled circle-Caco-2/ pRS26) cells, at different times $(5,24$ and $48 \mathrm{~h})$. **p<0.01 compared to untreated control cells (pRSctrl cells), $n=3$. d Intracellular LDH activity measured in non-treated and IL-1 $\beta(5 \mathrm{ng} / \mathrm{ml})$ treated Caco-2/pRSctrl and Caco-2/pRS26 cells incubated $48 \mathrm{~h}$ in serumfree medium, and expressed as LDH activity \%, taken the values of Caco-2/pRSctrl as $100 \%$. One-way ANOVA and Tukey's test were performed. ${ }^{*} p<0.05, n=4$ independent experiments. Kruskal-Wallis test and the Mann-Whitney test were used to corroborate significant difference by a non-parametric analysis and the results were equivalent

than oxamate. As shown in Fig. 7b, the three inhibitors used, oxamate (60 mM), GNE-140 (1 $\mu \mathrm{M})$, and GSK2837808A $(1 \mu \mathrm{M})$, caused a pHe increase in IB3-1 cells, while in C38 cells, a small pHe increase was observed, that did not reach significance. GNE-140 (racemate) was slightly more potent than GSK2837808A at the same concentration of $1 \mu \mathrm{M}$.

\section{Discussion}

Here, we show that Caco-2/pRS26 colon carcinoma cells or IB3-1 CF lung epithelial cells, both with impaired CFTR activity, cultured in monolayers, produce a reduction in the pHe (Fig. 1) concomitant with an increased lactate secretion 
Fig. 4 JNK and c-Src inhibitors SP600125 and PP2 increased the pHe in cells with impaired CFTR activity. a pHe measured in conditioned media from Caco-2/pRSctrl cells (open bars) and Caco-2/ pRS26 (closed bars) cells, previously incubated in serum-free medium for $24 \mathrm{~h}$, and then treated for $48 \mathrm{~h}$ with inhibitors of the IL-1 $\beta$ pathway $(5 \mu \mathrm{M}$ IKK-2 inhibitor SC-514, $10 \mu \mathrm{M}$ c-Src inhibitor PP2, $5 \mu \mathrm{M}$ P38 inhibitor SB203580, $5 \mu \mathrm{M}$ MEK1/2 inhibitor U0126, and $5 \mu \mathrm{M}$ JNK inhibitor SP600125) with the replenishment of fresh media at time zero. ${ }^{*} p<0.05$ compared to Caco- $2 / \mathrm{pRS}$ ctrl cells. One-way ANOVA and Tukey's test for $n=3$ independent experiments were performed. b Dose-response curve corresponding to $\mathrm{pHe}$ measured in conditioned media from Caco-2/pRSctrl cells (solid line) and Caco-2/pRS26 (dotted line) cells, treated for $48 \mathrm{~h}$ with the JNK inhibitor SP600125. c Dose-response obtained by incubation with the c-Src inhibitor PP2 in the same conditions as b. The dose-response curves were fitted with a sigmoidal function and $t$ values were calculated from $R^{2}$ ( $p<0.001$ in $\mathbf{b}$ and $\left.\mathbf{c}\right)$. $* p<0.05$, comparing the values of Caco-2/pRS26 at each concentration with the values of Caco-2/ pRSctrl cells at the same concentration, using the Student $t$ test $(n=4$ independent experiments). Kruskal-Wallis test and the Mann-Whitney test were used to corroborate significant difference by a non-parametric analysis and the results were equivalent

(Fig. 2). The pHe reduction is small, $\sim 0.2 \mathrm{pH}$ units, since the cultured medium is buffered with HEPES and bicarbonate. The contribution of this small reduction to the CF pathophysiology is unknown. However, lactate concentration in the culture medium after $48 \mathrm{~h}$ incubation reached values of $\sim 12 \mathrm{mM}$ for Caco-2/pRS26 and $6 \mathrm{mM}$ for IB3-1 cells in $72 \mathrm{~h}$. Since lactate is secreted together with $\mathrm{H}^{+}$through lactate $/ \mathrm{H}^{+} \mathrm{MCTs}$ symporters (monocarboxylate transporters) [43-45], probably the measured lactate is equivalent to lactic acid. For this reason, the pHe decreases when the measured lactate increases. However, other routes have been proposed for lactate efflux and $\mathrm{H}^{+}$secretion and might also contribute to the $\mathrm{pHe}$.

In IB3-1 cells (derived from a CF patient), cultured in serum-free medium, the lactate secretion increased lineally at least up to $48 \mathrm{~h}$. The increased lactic acid secretion was accompanied by increased LDH activity and LDH-A expression. The influence of 5\% FBS in the LDH-A expression, measured by cytometry, was minimal and did not reach significance (Fig. 2a-d). Similar results in lactate secretion and LDH activity were obtained when IB3-1 CF cells were compared to "CFTR-corrected" C38 cells (Fig. 2e, f). The lactate secretion was higher in Caco-2 colon cells $(\sim 6 \mathrm{mM} /$ day) than in IB3-1 the lung cells ( $2 \mathrm{mM} /$ day). This is probably due to the fact that Caco- 2 cells are derived from tumor cells, while IB3-1 cells are derived from non-tumor cells. It is interesting to note that, in agreement with these results, before the CFTR was cloned, Bardon et al. [50, 51] reported several disturbs in the glycolytic pathway of CF cells, and that the activity of hexokinase, phosphofructokinase, pyruvate kinase, and lactate dehydrogenase were increased in fibroblasts from CF patients. However, when the CFTR was cloned and found to be a $\mathrm{Cl}^{-}$channel, these observations regarding possible metabolic changes in $\mathrm{CF}$ were neglected,
A
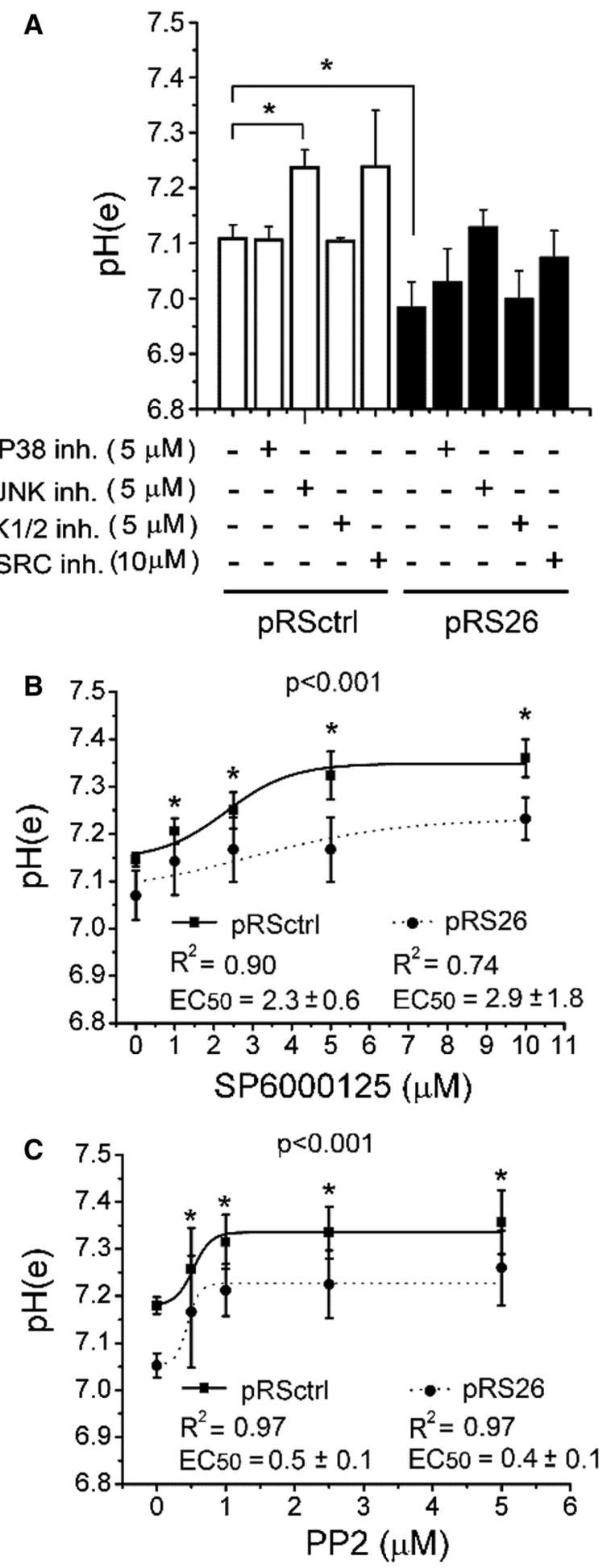

as occurred with other work by Burton Shapiro concerning possible mitochondrial failures in CF [19, 52, 53]. It was not known at that time that $\mathrm{Cl}^{-}$might act as a signaling effector, inducing the expression of $\mathrm{Cl}^{-}$-dependent genes [47, 49].

Although we did not measure IL- $1 \beta$ in the supernatants of C38 cells, we have shown previously that IB3-1 cells 
Fig. 5 Lactate secretion and intracellular LDH activity in cells treated with the JNK and c-Src inhibitors SP600125 and PP2. a Lactate secreted into the culture media of Caco-2/pRSctrl and Caco-2/pRS26 cells treated with $10 \mu \mathrm{M}$ SP600125 (JNK inhibitor), at $0,5,24$ and $48 \mathrm{~h}$. b Intracellular LDH activity in Caco-2/pRSctrl and Caco-2/ pRS26 cells treated with $10 \mu \mathrm{M}$ SP600125 for $48 \mathrm{~h}$. LDH activity was expressed as \%, normalized to Caco-2/pRSctrl as $100 \%$ activity. c Lactate concentration secreted into the culture media of Caco-2/pRSctrl and Caco-2/ pRS26 cells treated with $5 \mu \mathrm{M}$ PP2 (c-Src inhibitor), at 0, 5, 24 and $48 \mathrm{~h}$. d Intracellular LDH activity in Caco-2/pRSctrl and Caco-2/pRS26 cells treated with $5 \mu \mathrm{M}$ PP2 for $48 \mathrm{~h}$. One-way ANOVA and Tukey's test were used ( $n=3$, independent experiments). Kruskal-Wallis test and the Mann-Whitney test were used to corroborate significant difference by a non-parametric analysis and the results were equivalent
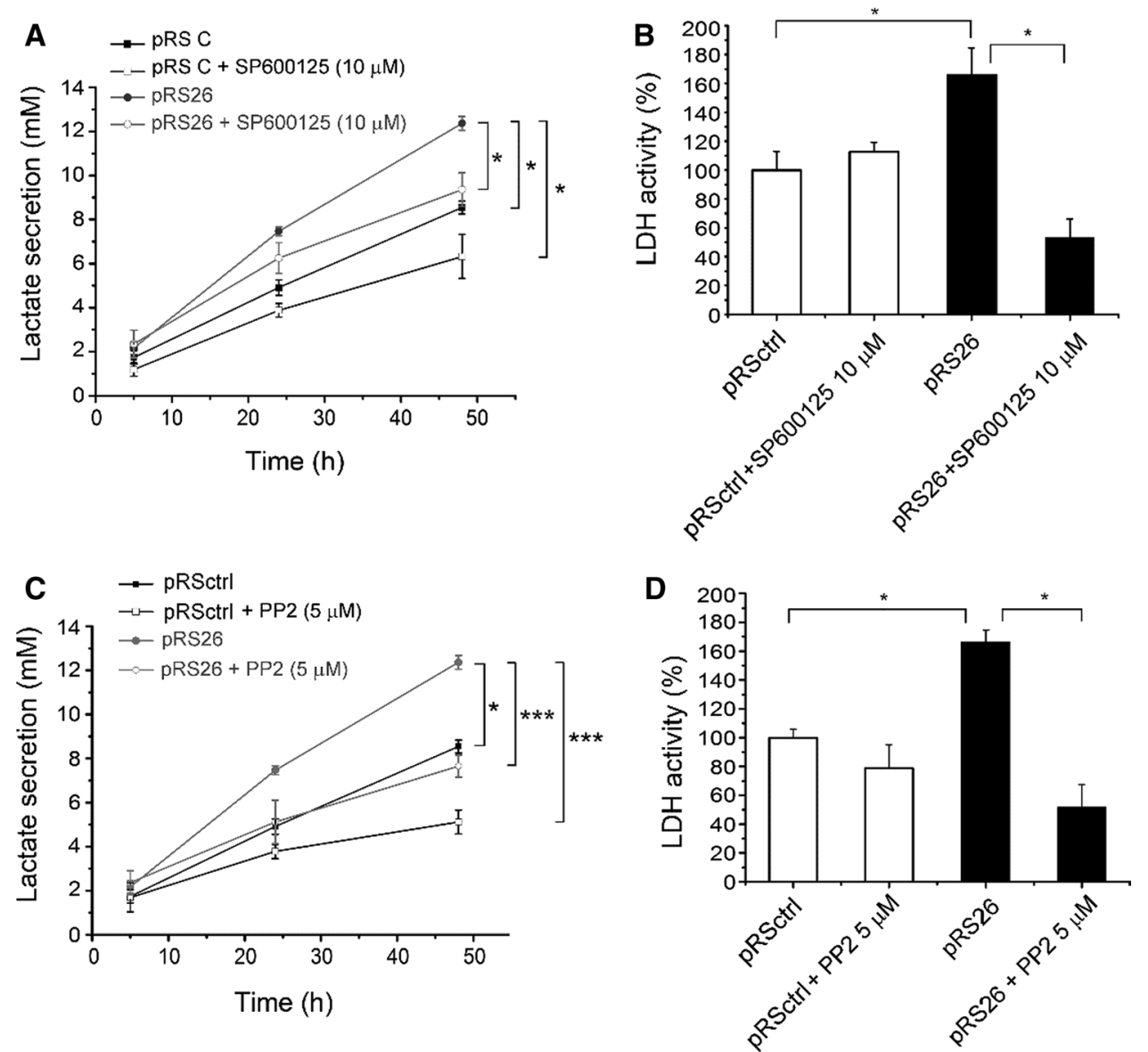

overexpress IL- $1 \beta$ compared to "CFTR-corrected" $S 9$ cells [21], which are also IB3-1 cells transfected with wt-CFTR. The same was the case for Caco- $2 / \mathrm{pRS} 26$ cells, which overexpress IL- $1 \beta$ compared to Caco-2/pRSctrl control cells [21]. Therefore, we decided to test the pHe effects of adding recombinant IL- $1 \beta$ and several inhibitors of the IL- $1 \beta$ pathway to Caco-2/pRSctrl cells. IL-1 $\beta$, added to cultured Caco-2/pRSctrl cells, produced a pHe reduction, reaching a similar pHe value compared to Caco2/pRS26 cells (with shRNA-CFTR) when the IL- $1 \beta$ concentration was over $1 \mathrm{ng} /$ $\mathrm{ml}$ (Fig. 3). This pHe decreased in Caco-2/pRSctrl cells treated with IL-1 $\beta$ was also accompanied by increased LDH activity and lactate secretion, suggesting that the effects seen in these cells are partially due to the previously described IL-1 $\beta$ autocrine loop $[21,26,46,48]$. Therefore, we decided to study the effects of inhibitors of the IL- $1 \beta$ signaling pathway, including p38, JNK, MEK1/2 and c-Src inhibitors. The c-Src and JNK inhibitors (PP2 and SP600125, respectively) increased the pHe in cells with impaired CFTR activity (Fig. 4). However, control cells also increased the pHe and, therefore, the impaired cells were not able to fully recover the pHe with these inhibitors (both inhibitors added together did not showed further pHe recovery; results not shown). Thus, some other pathways besides those of c-Src and JNK might partially contribute to the increased pHe. These inhibitors also significantly reduced the lactic acid secretion and LDH activity in Caco-2/pRS26 cells (Fig. 5a-d). On the other hand, contrary to results obtained using JNK and c-Src inhibitors, a full recovery in the $\mathrm{pHe}$ was observed when Caco-2/pRS26 cells were treated with oxamate, an LDH inhibitor (Fig. 6). Similar results were obtained using IB3-1 and C38 cells, although the recovery was not total in this case, and a small difference remains (Fig. 7). Altogether, these data suggest that an increased LDH activity and lactate secretion are responsible for the decreased $\mathrm{pHe}$ observed, induced by the CFTR failure. Interestingly, in the last years, several reports supports the hypothesis of an impaired $\mathrm{HCO}_{3}{ }^{-}$transport in $\mathrm{CF}$ as the cause for a decreased $\mathrm{pHe}$ in the ASL [7, 54]. However, the possible contribution of lactate was not considered in those studies. By the contrary, the present results suggest that lactic acid is the main factor determining the reduced $\mathrm{pHe}$, and that the contribution by bicarbonate in these cells, if any, should be minimal (since LDH inhibition by oxamate completely normalizes the $\mathrm{pHe}$ in Caco2/pRS26 cells and almost completely in IB3-1 cells). Nevertheless, we cannot disregard some contribution of a reduced $\mathrm{HCO}_{3}{ }^{-}$secretion without a direct measurement of its concentration. 
Fig. 6 Oxamate treatment normalized the pHe and lactate values of Caco-2/pRS26 cells. a pHe was measured in conditioned media from Caco-2/pRSctrl and Caco-2/pRS26 cells, previously incubated in serum- free medium for $24 \mathrm{~h}$, and treated with different oxamate concentrations $(0-60 \mathrm{mM})$ for $48 \mathrm{~h}$. pHe vs oxamate concentration points were fitted using a sigmoidal (dose-response) function fixing the low asymptote to $0 \mathrm{mM}$ concentration and the $t$ values were calculated from the $R^{2}(p<0.001)$. b Lactate secreted into the culture media of Caco-2/pRSctrl and Caco-2/pRS26 cells treated with $60 \mathrm{mM}$ oxamate, at $0,5,24$, and $48 \mathrm{~h})$. $* * * p<0.001$ with respect to pRS26 cells at $48 \mathrm{~h}$ (ANOVA one-way-Tukey's test). $\mathbf{c}$ Intracellular LDH activity of Caco-2/pRSctrl and Caco-2/pRS26 cells treated with $60 \mathrm{mM}$ oxamate for $48 \mathrm{~h}$. LDH activity was expressed as \% and referred to Caco-2/ pRSctrl as $100 \%$ of activity. ${ }^{*} p<0.05$ with respect to Caco-2/pRS26 cells at $48 \mathrm{~h}$ (ANOVA one-way-Tukey's test, $n=3$ independent experiments). Kruskal-Wallis test and the Mann-Whitney test were used to corroborate significant difference by a non-parametric analysis and the results were equivalent

In consonance with the effects of IL- $1 \beta$ observed here, Abcouwer et al. [55] showed an increased lactate production and a decreased mitochondrial activity in retinal neurons treated with IL-1 $\beta$ and Manerba et al. found that TNF and IL-17 increased LDH-A activity and lactate production in cancer cells, affecting the migration ability and matrix remodeling; the LDH inhibitors oxamate and galloflavin were found to relieve the inflammation-induced effects [56]. In addition, Wetmore et al. found several metabolic differences between the CF and non-CF cells [57] and Bensel et al. [58] found increased levels of lactate in sputum from CF patients, attributed to the anaerobic metabolism of neutrophils in the relative hypoxic conditions of CF secretions. In addition, Kottmann et al. [59] reported an increased lactate production in idiopathic pulmonary fibrosis (IPF), a disease phenotypically similar to CF; in human lung fibroblasts, they showed a pH-dependent activation of transforming growth factor beta (TGF- $\beta$ ), accompanied by LDH5 overexpression. It should be noted, however, that the levels of lactate in airways or sputum could not only be attributed to the CFTR failure of epithelial cells, since the presence of active inflammatory cells and bacteria will result in elevation of lactate independently of the CFTR mutation.

While this work was in progress, Schultz el al. [9] reported that the ASL $\mathrm{pH}$ was not changed in CF children or in primary cell cultured in the presence of serum. However, they did see a $\mathrm{pH}$ reduction in cells cultured in the absence of serum. Clearly, the pHe is reduced only after the buffer capacity of the media (or ASL) is exceed. We performed our studies in the absence of serum to avoid the FBS buffering and to have a very well-defined cultured condition. An important question here is how much FBS is equivalent to the in vivo environment [60]. In other words, we need to know how much FBS should be added to correctly emulate the in vivo environment. This has not been studied yet. On the other hand, primary cells are usually cultured in semisynthetic media that have EGF, crude pituitary extracts
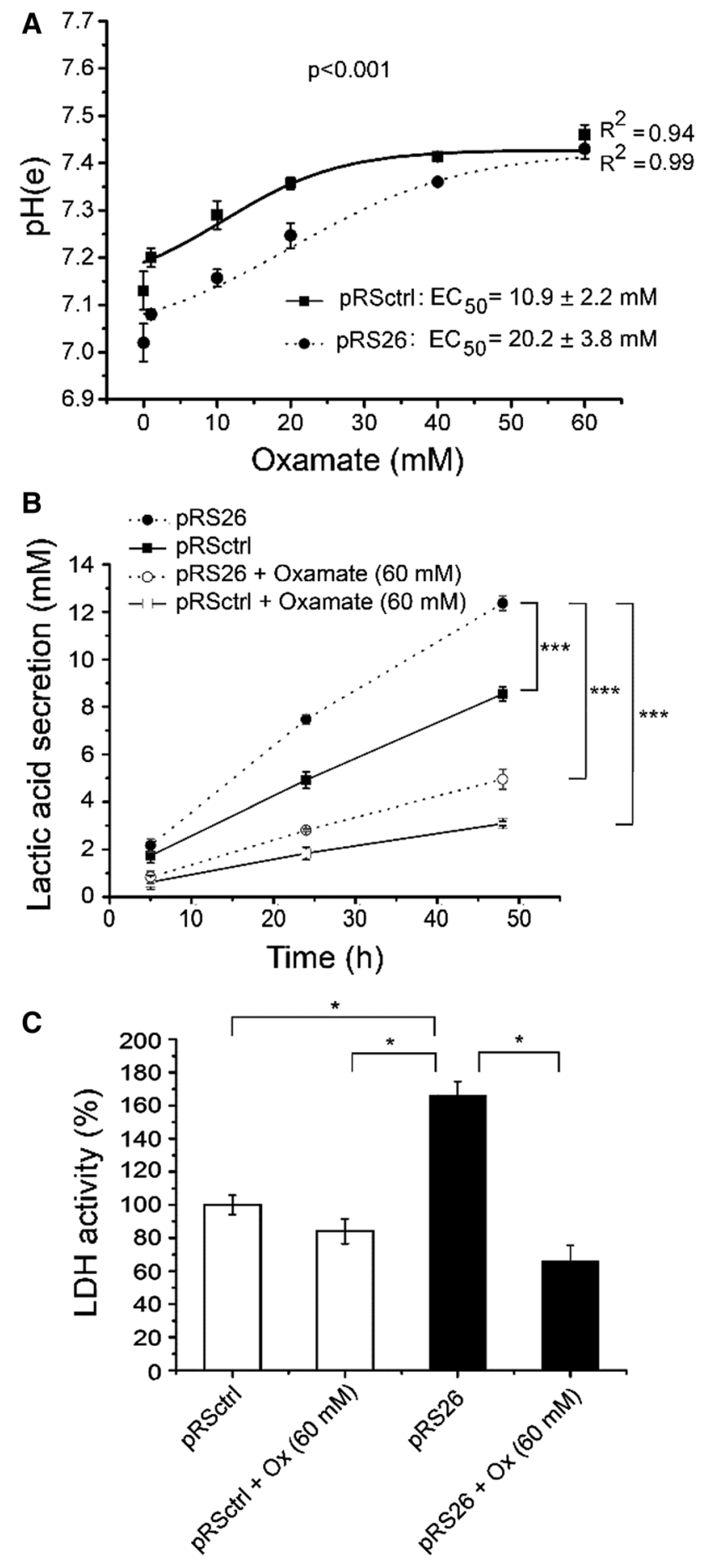

and other substances of an unknown composition and it is unknown in which degree the excessive presence of EGF and other factors affect the pHe (and the CFTR expression). Therefore, the results from the different model systems might not be analogous. Thus, the results by Schultz et al. [9] contradict the previous results obtained in the pig model or in lungs lavages from CF patients (recently reviewed in [10]); in consequence, the issue is still controversial [10]. 


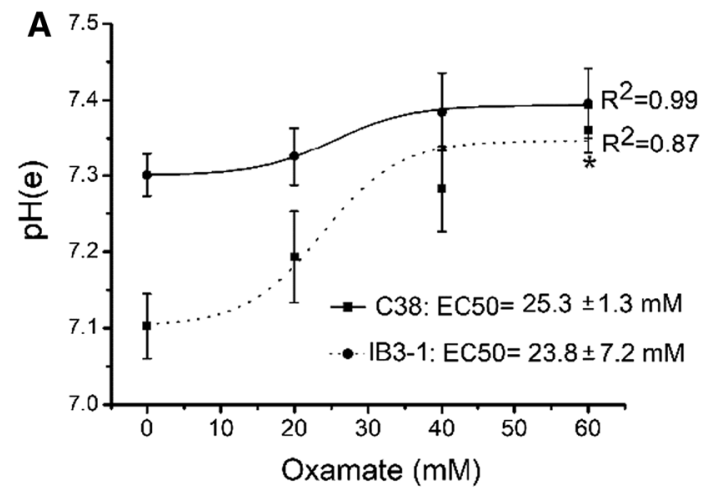

Fig. 7 Oxamate and the more potent LDH-A inhibitors GNE-140 and GSK-2837808A also increased the pHe values of IB3-1 CF lung epithelial cells. a pHe was measured in IB3-1 and C38 cells treated with different oxamate concentrations $(0-60 \mathrm{mM})$ in serum-free medium for $72 \mathrm{~h}$. pHe vs oxamate concentration points were fitted using a sigmoidal function. b pHe was measured in IB3-1 and C38 cells treated

What is clear from the present results is that LDH activity and lactate productions increase when the CFTR activity is impaired. In which conditions the increased lactate might exceed the buffer capacity of the basolateral fluids in vivo and then decrease the $\mathrm{pHe}$ in the apical region through the basolateral shunt or direct apical secretion is still unknown. Earlier studies in sweat glands [61] showed that lactate was secreted at the same rate as bicarbonate, and differences between normal and $\mathrm{CF}$ individual were not observed in lactate, bicarbonate, and pHe. Perhaps, for this reason, the lactate was no longer considered a factor. It is clear now that at least for these cultured epithelial cells from lung (IB3-1 cells) and intestine (Caco- 2 cells), this is not the case, and that lactate has a predominant role in determining the $\mathrm{pHe}$ when the buffer capacity is exceeded. However, in other epithelial cells, particularly in pancreas, were bicarbonate secretion is abundant [62], the acidification as a result of lactate secretion may be compensated or exceeded by the bicarbonate secretion through CFTR or other anion channels. In addition, it should be noted that Caco- 2 cells are derived from a colon carcinoma. Therefore, in agreement with the obtained results, these tumor cells are expected to have a s stronger Warburg effect and lactate production compared to the IB3-1 cells, which are non-tumor cells derived from a $\mathrm{CF}$ patient.

In addition, while this work was in progress, and in agreement with our results, Garnett et al. [63] found that primary human bronchial epithelial cells (HBE) secrete lactate into the ASL; this was elevated in hyperglycemic conditions, leading to ASL acidification in CF-HBE cells. This effect was mimicked in $\mathrm{HBE}$ cells by $\mathrm{HCO}_{3}{ }^{-}$removal.

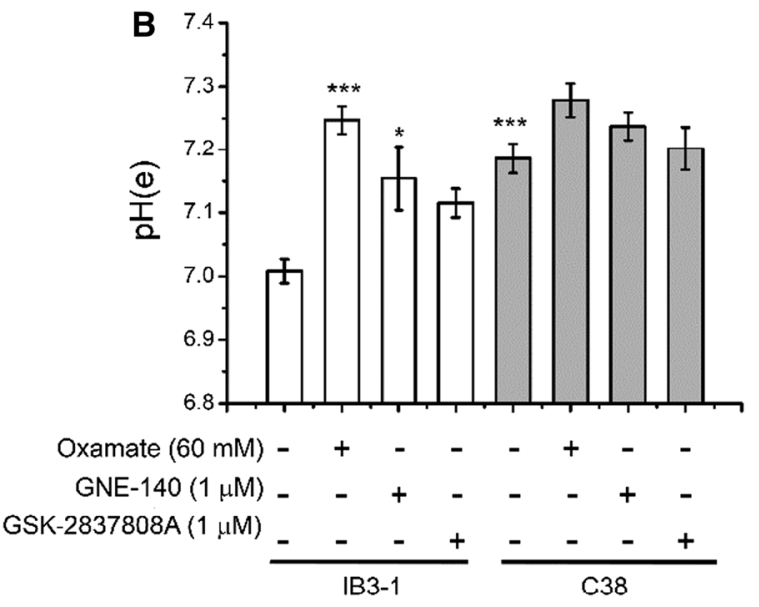

with oxamate $(60 \mathrm{mM})$ and with two additional LDH-A inhibitors, GNE-140 $(1 \mu \mathrm{M})$ and GSK-2837808A $(1 \mu \mathrm{M})$. *** $p<0.001$ with respect to control untreated IB3-1 cells (ANOVA one-way-Tukey's test, $n=3$ independent experiments). Kruskal-Wallis test and the Mann-Whitney test were used to corroborate significant difference by a non-parametric analysis and the results were equivalent

The increased lactate and reduced ASL $\mathrm{pH}$ were exacerbated in the presence of $P$. aeruginosa and attenuated by incubation with the monocarboxylate lactate- $\mathrm{H}^{+}$co-transporters (MCTs) inhibitor AR-C155858. The authors concluded that hyperglycemia and $P$. aeruginosa induce a metabolic shift which increases lactate generation and efflux into the ASL via MCT2 transporters. They also suggest that normal cells compensate the lactate excess and acidification by secreting $\mathrm{HCO}_{3}{ }^{-}$and postulate that $\mathrm{CF}$ cells cannot do this due to the CFTR failure. However, we show here that, in cells with impaired CFTR activity, the main reason for the decreased $\mathrm{pHe}$ seems to be the excess of lactic acid, due to increased LDH expression and activity, which occur here under sterile conditions. Garnett et al. showed that in the presence of $P$. aeruginosa infection, the lactic acid production is worsened. Unfortunately, they measure lactate production at $5 \mathrm{mM}$ and $15 \mathrm{mM}$ glucose only in HBE, H441, and Calu-3 cells, but not in CF-HBE cells to compare the lactate secretion in normal and CF cells. Thus, they attributed the differences in the ASL pH only to $P$. aeruginosa exposure and to a reduced $\mathrm{HCO}_{3}{ }^{-}$secretion in CF cells. Our results became clear that cells with impaired CFTR activity (IB3-1 and Caco-2/pRS26 cells) reduce the pHe mainly due to differences in lactic acid production. On the other hand, one very important observation of Garnett et al. [63] was that changes in the ASL pH were observed only under hyperglycemia or in the presence of $P$. aeruginosa. This may explain why changes in the ASL $\mathrm{pH}$ sometimes could not be found in vivo, depending on the levels of glucose or the extension of the infected areas. Perhaps, the differences are only apparent in the areas of infection and exacerbated in the presence of CF related diabetes 


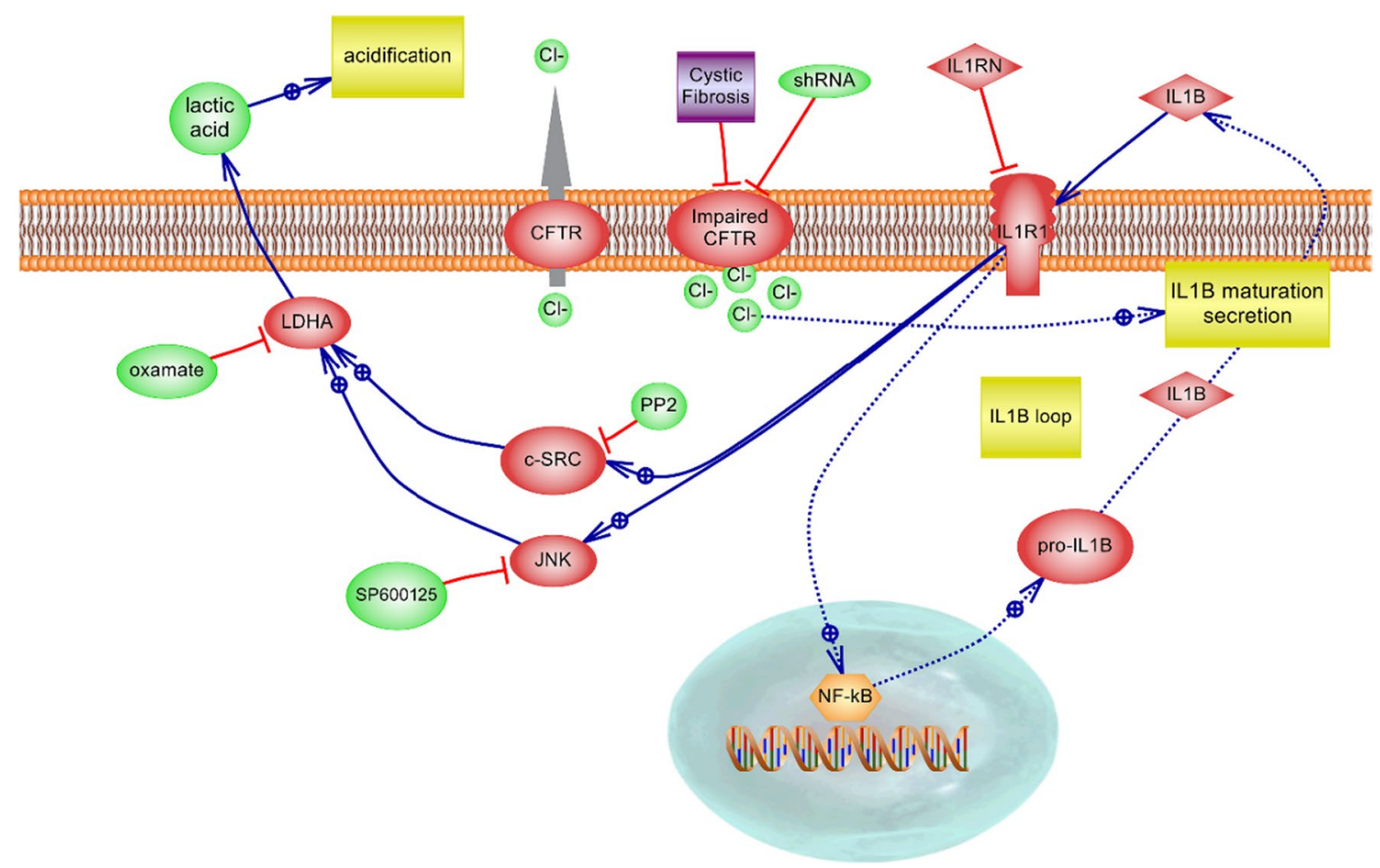

Fig. 8 Graphical summary of results and postulated mechanism. The CFTR failure induces intracellular $\mathrm{Cl}^{-}$accumulation [47, 49], produces IL-1 $\beta$ secretion [21, 48], inhibition of mCx-I [16, 19, 20], increased c-Src activity and ROS levels [21, 26, 68]. This leads to the activation of $\mathrm{LDH}$, production/secretion of lactate, and reduction

(CFRD), as the authors suggested. More interestingly, they showed that in the absence of bicarbonate (with HEPES), the apical $P$. aeruginosa CFU increased significantly and even more in the presence of high glucose $(15 \mathrm{mM})$, suggesting that CFRD and acidity contribute to worsen infections [63]. On the other hand, in addition to reduce the $\mathrm{pH}$, the increased lactate may contribute to the development of infections by supplying a carbon source to bacteria [64]. In addition, particularly in diabetic patients, the glucose metabolism in bacteria may be an additional source of lactate, contributing to a reduced $\mathrm{pH}$ environment and to the microfilm formation $[64,65]$.

Figure 8 summarizes the results obtained here and in the previous works of our laboratory $[20,21]$. According to the results obtained so far, the signaling pathway leading to increased lactate production in cells with impaired CFTR activity appears to follow the following sequence of events: impaired CFTR $\rightarrow \mathrm{Cl}^{-}$accumulation $\rightarrow$ increased IL-1 $\beta$ secretion $\rightarrow$ IL- $1 \beta$ signaling $\rightarrow$ reduced $\mathrm{mCx}-\mathrm{I} \rightarrow$ increased LDH and lactic acid secretion, and eventually, a reduced pHe. Thus, oxamate or other LDH inhibitors, which are being developed to treat cancer [24, 66, 67], might be useful to correct the increased glycolytic pathway observed in $\mathrm{CF}$ patients, perhaps reducing their susceptibility to infections of the pHe, partially through c-Src and JNK signaling pathways. In Caco-2/pRS26 cells the LDH and the lactate contribute entirely to the reduction of $\mathrm{pHe}$, since oxamate completely reverted the low $\mathrm{pHe}$ of these CFTR-KD cells to the value of control cells. Doted lines (...) represent previously obtained results

due to the low pHe sometimes observed in this patients [5-7]. However, further studies are needed to better understand how LDH is regulated by CFTR signaling (or IL- $1 \beta$ signaling) and its role in determining the $\mathrm{pHe}$ in vivo.

Acknowledgements We thank Professor Diego Battiato and Romina D’Agostino for administrative assistance, and María de los Angeles Aguilar for technical assistance. We also thank Dr. Lutz Birnbaumer for his continuous support to our work and very valuable criticisms. This work was supported by National Agency for the Promotion of Science and Technology (ANPCYT) [grant numbers PICT 2012-1278 to TASC and PICT-2015-1031 to AGV]; National Scientific and Technical Research Council of Argentina (CONICET) [grants PIP-2016 112201-501002-27 and PUE-2016 22920160100129CO to TASC]; and Pontifical Catholic University of Argentina (UCA) to TASC. Fellowships from CONICET to MMC, CM, and MC.

\section{References}

1. Riordan JR et al (1989) Identification of the cystic fibrosis gene: cloning and characterization of complementary DNA. Science 245(4922):1066-1073

2. Sheppard DN, Welsh MJ (1999) Structure and function of the CFTR chloride channel. Physiol Rev 79(1 Suppl):S23-S45

3. Rommens JM et al (1991) cAMP-inducible chloride conductance in mouse fibroblast lines stably expressing the human cystic 
fibrosis transmembrane conductance regulator. Proc Natl Acad Sci USA 88(17):7500-7504

4. Althaus $\mathrm{M}$ (2013) ENaC inhibitors and airway re-hydration in cystic fibrosis: state of the art. Curr Mol Pharmacol 6(1):3-12

5. Chen JH et al (2010) Loss of anion transport without increased sodium absorption characterizes newborn porcine cystic fibrosis airway epithelia. Cell 143(6):911-923

6. Rogers CS et al (2008) Disruption of the CFTR gene produces a model of cystic fibrosis in newborn pigs. Science 321(5897):1837-1841

7. Pezzulo AA et al (2012) Reduced airway surface pH impairs bacterial killing in the porcine cystic fibrosis lung. Nature 487(7405):109-113

8. McShane D et al (2003) Airway surface pH in subjects with cystic fibrosis. Eur Respir J 21(1):37-42

9. Schultz A et al (2017) Airway surface liquid pH is not acidic in children with cystic fibrosis. Nat Commun 8(1):1409

10. Massip-Copiz MM, Santa-Coloma TA (2018) Extracellular pH and lung infections in cystic fibrosis. Eur J Cell Biol 97:402-410

11. Figueira MF, Webster MJ, Tarran R (2018) CrossTalk proposal: mucosal acidification drives early progressive lung disease in cystic fibrosis. J Physiol 596(16):3433-3437

12. González Guerrico AM et al (1999) Abstract M238 [El gen c-src es un posible marcador funcional del canal de cloruro afectado en fibrosis quística: CFTR]. In: 35th Annual meeting of the argentine society for biochemistry and molecular biology research (SAIB), November 9-12, Mendoza, Argentina (abstracts book)

13. Cafferata EG et al (1995) Abstract M99 [Identificación mediante "differential display" de genes específicamente regulados por diferentes factores que afectan la expresión del CFTR (canal de cloro afectado en Fibrosis Quística)] Abstracts of the 31th annual meeting of the Argentine Society for biochemistry and molecular biology research (SAIB), 15-18 November, Villa Giardino, Córdoba (abstracts book)

14. Gonzalez-Guerrico AM et al (2002) Tyrosine kinase c-Src constitutes a bridge between cystic fibrosis transmembrane regulator channel failure and MUC1 overexpression in cystic fibrosis. J Biol Chem 277(19):17239-17247

15. Estell K et al (2003) Plasma membrane CFTR regulates RANTES expression via its C-terminal PDZ-interacting motif. Mol Cell Biol 23(2):594-606

16. Valdivieso AG et al (2007) The expression of the mitochondrial gene MT-ND4 is downregulated in cystic fibrosis. Biochem Biophys Res Commun 356(3):805-809

17. Taminelli GL et al (2008) CISD1 codifies a mitochondrial protein upregulated by the CFTR channel. Biochem Biophys Res Commun 365(4):856-862

18. Hofhaus G, Attardi G (1993) Lack of assembly of mitochondrial DNA-encoded subunits of respiratory NADH dehydrogenase and loss of enzyme activity in a human cell mutant lacking the mitochondrial ND4 gene product. EMBO J 12(8):3043-3048

19. Valdivieso AG, Santa-Coloma TA (2013) CFTR activity and mitochondrial function. Redox Biol 1(1):190-202

20. Valdivieso AG et al (2012) The mitochondrial complex I activity is reduced in cells with impaired cystic fibrosis transmembrane conductance regulator (CFTR) function. PLoS One 7(11):e48059

21. Clauzure $\mathrm{M}$ et al (2014) Disruption of interleukin-1beta autocrine signaling rescues complex I activity and improves ROS levels in immortalized epithelial cells with impaired cystic fibrosis transmembrane conductance regulator (CFTR) function. PLoS One 9(6):e99257

22. Warburg O (1956) On the origin of cancer cells. Science 123(3191):309-314

23. Alfarouk KO et al (2014) Glycolysis, tumor metabolism, cancer growth and dissemination. A new $\mathrm{pH}$-based etiopathogenic perspective and therapeutic approach to an old cancer question. Oncoscience 1(12):777-802

24. Zhou M et al (2010) Warburg effect in chemosensitivity: targeting lactate dehydrogenase-A re-sensitizes taxol-resistant cancer cells to taxol. Mol Cancer 9:33

25. Robinson BH (2006) Lactic acidemia and mitochondrial disease. Mol Genet Metab 89(1-2):3-13

26. Massip-Copiz MM et al (2017) CFTR impairment upregulates c-Src activity through IL-1beta autocrine signaling. Arch Biochem Biophys 616:1-12

27. Zeitlin PL et al (1991) A cystic fibrosis bronchial epithelial cell line: immortalization by adeno-12-SV40 infection. Am J Respir Cell Mol Biol 4(4):313-319

28. Bargon J et al (1992) Expression of the cystic fibrosis transmembrane conductance regulator gene can be regulated by protein kinase C. J Biol Chem 267(23):16056-16060

29. Shoshani T et al (1992) Association of a nonsense mutation (W1282X), the most common mutation in the Ashkenazi Jewish cystic fibrosis patients in Israel, with presentation of severe disease. Am J Hum Genet 50(1):222-228

30. Zeitlin PL et al (1992) CFTR protein expression in primary and cultured epithelia. Proc Natl Acad Sci USA 89(1):344-347

31. Flotte TR et al (1993) Stable in vivo expression of the cystic fibrosis transmembrane conductance regulator with an adeno-associated virus vector. Proc Natl Acad Sci USA 90(22):10613-10617

32. Flotte TR et al (1993) Expression of the cystic fibrosis transmembrane conductance regulator from a novel adeno-associated virus promoter. J Biol Chem 268(5):3781-3790

33. Purkey HE et al (2016) Cell active hydroxylactam inhibitors of human lactate dehydrogenase with oral bioavailability in mice. ACS Med Chem Lett 7(10):896-901

34. Brighenti E et al (2017) The inhibition of lactate dehydrogenase A hinders the transcription of histone $2 \mathrm{~B}$ gene independently from the block of aerobic glycolysis. Biochem Biophys Res Commun 485(4):742-745

35. Chen EP et al (1989) Inactivation of lactate dehydrogenase by UV radiation in the $300 \mathrm{~nm}$ wavelength region. Radiat Environ Biophys 28(3):185-191

36. Schmid I, Uittenbogaart CH, Giorgi JV (1991) A gentle fixation and permeabilization method for combined cell surface and intracellular staining with improved precision in DNA quantification. Cytometry 12(3):279-285

37. Brady KD et al (1994) Relationships between amplitudes and kinetics of rapid cytosolic free calcium fluctuations in GH4C1 rat pituitary cells: roles for diffusion and calcium-induced calcium release. Biophys J 66(5):1697-1705

38. Levene H (1960) Robust tests for equality of variances in contributions to probability and statistics: essays in honor of Harold Hotelling, I. Olkin, et al., editors. Stanford University Press, Palo Alto, pp 278-292

39. Shapiro SS, Wilk MB (1965) An analysis of variance test for normality (complete samples). Biometrika 52(3-4):591-611

40. Kruskal WH, Wallis WA (1952) Use of ranks in one-criterion variance analysis. J Am Stat Assoc 47(260):583-621

41. Mann HB, Whitney DR (1947) On a test of whether one of two random variables is stochastically larger than the other. Ann Math Stat 18(1):50-60

42. Student (Gossett W.S.) (1907) On the error of counting with a haemacytometer. Biometrika 5(3):351-360

43. Counillon $\mathrm{L}$ et al $(2016) \mathrm{Na}(+) / \mathrm{H}(+)$ antiporter (NHE1) and lactate/H(+) symporters (MCTs) in $\mathrm{pH}$ homeostasis and cancer metabolism. Biochim Biophys Acta 1863(10):2465-2480

44. Halestrap AP (2013) The SLC16 gene family-structure, role and regulation in health and disease. Mol Aspects Med 34(2-3):337-349 
45. Halestrap AP (2013) Monocarboxylic acid transport. Compr Physiol 3(4):1611-1643

46. Massip-Copiz M et al (2018) Epiregulin (EREG) is upregulated through an IL-1beta autocrine loop in Caco-2 epithelial cells with reduced CFTR function. J Cell Biochem 119(3):2911-2922

47. Valdivieso AG et al (2017) CFTR modulates RPS27 gene expression using chloride anion as signaling effector. Arch Biochem Biophys 633:103-109

48. Clauzure $\mathrm{M}$ et al (2017) Intracellular chloride concentration changes modulate IL-1beta expression and secretion in human bronchial epithelial cultured cells. J Cell Biochem 118(8):2131-2140

49. Valdivieso AG et al (2016) The chloride anion acts as a second messenger in mammalian cells-modifying the expression of specific genes. Cell Physiol Biochem 38(1):49-64

50. Bardon A (1987) Cystic fibrosis. Carbohydrate metabolism in CF and in animal models for CF. Acta Paediatr Scand Suppl 332:1-30

51. Bardon A, Ceder O, Kollberg H (1986) Increased activity of four glycolytic enzymes in cultured fibroblasts from cystic fibrosis patients. Res Commun Chem Pathol Pharmacol 51(3):405-408

52. Shapiro BL (1988) Mitochondrial dysfunction, energy expenditure, and cystic fibrosis. Lancet 2(8605):289

53. Shapiro BL, Feigal RJ, Lam LF (1979) Mitrochondrial NADH dehydrogenase in cystic fibrosis. Proc Natl Acad Sci USA 76(6):2979-2983

54. Quinton PM (2007) Cystic fibrosis: lessons from the sweat gland. Physiology (Bethesda) 22:212-225

55. Abcouwer SF et al (2008) Effect of IL-1beta on survival and energy metabolism of R28 and RGC-5 retinal neurons. Invest Ophthalmol Vis Sci 49(12):5581-5592

56. Manerba $\mathrm{M}$ et al (2017) Lactate dehydrogenase inhibitors can reverse inflammation induced changes in colon cancer cells. Eur J Pharm Sci 96:37-44

57. Wetmore DR et al (2010) Metabolomic profiling reveals biochemical pathways and biomarkers associated with pathogenesis in cystic fibrosis cells. J Biol Chem 285(40):30516-30522

58. Bensel $\mathrm{T}$ et al (2011) Lactate in cystic fibrosis sputum. J Cyst Fibros 10(1):37-44
59. Kottmann RM et al (2012) Lactic acid is elevated in idiopathic pulmonary fibrosis and induces myofibroblast differentiation via $\mathrm{pH}$-dependent activation of transforming growth factor-beta. Am J Respir Crit Care Med 186(8):740-751

60. Ye X, Lotan R (2008) Potential misinterpretation of data on differential gene expression in normal and malignant cells in vitro. Brief Funct Genom Proteom 7(4):322-326

61. Bijman J, Quinton PM (1987) Lactate and bicarbonate uptake in the sweat duct of cystic fibrosis and normal subjects. Pediatr Res 21(1):79-82

62. Ishiguro $\mathrm{H}$ et al (2012) Physiology and pathophysiology of bicarbonate secretion by pancreatic duct epithelium. Nagoya J Med Sci 74(1-2):1-18

63. Garnett JP et al (2016) Hyperglycaemia and Pseudomonas aeruginosa acidify cystic fibrosis airway surface liquid by elevating epithelial monocarboxylate transporter 2 dependent lactate$\mathrm{H}+$ secretion. Sci Rep 6:37955

64. Lin YC et al (2018) The pseudomonas aeruginosa complement of lactate dehydrogenases enables use of D- and L-lactate and metabolic cross-feeding. MBio 9(5):e00961-18

65. Silva IN et al (2017) Regulator LdhR and D-lactate dehydrogenase LdhA of burkholderia multivorans play roles in carbon overflow and in planktonic cellular aggregate formation. Appl Environ Microbiol 83(19):e01343-17

66. Miskimins WK et al (2014) Synergistic anti-cancer effect of phenformin and oxamate. PLoS One 9(1):e85576

67. Zhao $\mathrm{Z}$ et al (2015) Oxamate-mediated inhibition of lactate dehydrogenase induces protective autophagy in gastric cancer cells: involvement of the Akt-mTOR signaling pathway. Cancer Lett 358(1):17-26

68. Massip Copiz MM, Santa Coloma TA (2016) c- Src and its role in cystic fibrosis. Eur J Cell Biol 95(10):401-413

Publisher's Note Springer Nature remains neutral with regard to jurisdictional claims in published maps and institutional affiliations. 